\title{
Total Synthesis of Hypermodified Epothilone Analogs with Potent in vitro Antitumor Activity
}

C. N. Kuzniewski, J. Gertsch, M. Wartmann, K.-H. Altmann*

\section{Supporting Information I}

Experimental procedures and spectral data on all new compounds

$\underline{\text { Table of Contents }}$

General

S2

Synthesis of building block 4

S3

Synthesis of building block 5

S7

Assembly of target structures 1 and 2

S18

References

S21 
General: All solvents used for reactions were purchased as anhydrous grade from Fluka. Solvents for extractions, column chromatography and TLC were commercial grade and distilled before use. TLC was performed on Merck TLC aluminum sheets (silica gel $\left.60 \mathrm{~F}_{254}\right)$. Spots were visualized with UV light $(\lambda=254 \mathrm{~nm})$ or through staining with phosphomolybdic acid or $\mathrm{KMnO}_{4}$. Flash column chromatography (FC) was performed using Fluka silica gel 60 for preparative column chromatography (40$63 \mu \mathrm{m})$. Melting points were obtained in open capillary tubes using a Büchi melting point apparatus B-540 and are uncorrected. NMR spectra were recorded on a Bruker AV-400 $400 \mathrm{MHz}$ and a Bruker DRX-500 500MHz spectrometer at room temperature. Infrared spectra (IR) were recorded on a Jasco FT/IR-6200 instrument. Optical rotations were measured on a Jasco P-1020 polarimeter. HPLC analyses were carried out using a Waters Symmetry column (C18, 3.5 $\mu \mathrm{m}, 4.6 \times 100 \mathrm{~mm}$ ). Preparative HPLC was carried out using Waters Symmetry columns (C18, $5 \mu \mathrm{m}$, $7.8 \times 100 \mathrm{~mm}$ and $\mathrm{C} 18,5 \mu \mathrm{m}, 19 \times 100 \mathrm{~mm}$ ). 


\section{Synthesis of Building Block 4}

(2E)-2-4,4-Dimethyl-5-oxo-heptenoic acid methyl ester (7)<smiles>CCC(C)(C)C(C)(C)/C=C/C(=O)OC</smiles>

To a solution of methyl-diethylphosphono-acetate $(10.2 \mathrm{~g}, 48.0 \mathrm{mmol})$ in $50 \mathrm{ml}$ of THF was added dropwise a $1.6 \mathrm{M}$ solution of $n$-BuLi in hexane $(30.5 \mathrm{ml}, 48.0 \mathrm{mmol})$ at $0{ }^{\circ} \mathrm{C}$ under Ar. The mixture was stirred at $0{ }^{\circ} \mathrm{C}$ for $30 \mathrm{~min}$ and then cooled to -78 ${ }^{\circ} \mathrm{C}$. A solution of 2,2-dimethyl-3-oxo-pentanal ${ }^{\mathrm{S1}}(5 \mathrm{~g}, 39.0 \mathrm{mmol})$ in $10 \mathrm{ml}$ THF was then added dropwise over a period of $10 \mathrm{~min}$. After stirring at r.t. for $2 \mathrm{~h}$ the reaction was quenched with sat. aqu. $\mathrm{NH}_{4} \mathrm{Cl}$ and extracted 3 times with $20 \mathrm{ml}$ of $\mathrm{Et}_{2} \mathrm{O}$. The combined organic extracts were dried over $\mathrm{MgSO}_{4}$ and the solution was concentrated under reduced pressure. Purification of the residue by $\mathrm{FC}$ (hexane/Et $\mathrm{O}_{2} \mathrm{O}$ 9/1) afforded $6.0 \mathrm{~g}(83 \%)$ of ester 7 as a colorless liquid.

$\mathbf{R}_{\mathbf{f}}$ (hexane/acetone 1/1): 0.68 .

${ }^{1} \mathrm{H}$ NMR (400 MHz, $\mathrm{CDCl}_{3}$ ): $\delta 7.00(\mathrm{~d}, 1 \mathrm{H}, \mathrm{CH}=\mathrm{CH}), 5.85$ (d, $\left.1 \mathrm{H}, \mathrm{CH}=\mathrm{CH}\right), 3.75$ (s, $3 \mathrm{H}, \mathrm{OMe}$ ), 2.45 (q, 2H, $\mathrm{CH}_{3} \mathrm{CH}_{2}$ ), 1.25 (s, 6H, gemCH 3 ), 1.00 (t, 3H, $\mathrm{CH}_{3} \mathrm{CH}_{2}$ ).

${ }^{13} \mathrm{C}-\mathrm{NMR}$ (100 MHz, CDCl3): $\delta$ 8.3, 23.9, 31.7, 50.8, 52.0, 120.5, 152.3, 167.0, 211.8.

ESI-MS: $\mathrm{M}\left(\mathrm{C}_{10} \mathrm{H}_{16} \mathrm{O}_{3}\right)=184.2,\left(\mathrm{M}+\mathrm{H}_{2} \mathrm{O}\right)^{+}=202.0$.

$(6 R, 7 S, 8 S, E)-M e t h y l-7-h y d r o x y-9-(4-m e t h o x y b e n z y l o x y)-4,4,6,8$-tetramethyl-5oxonon-2-enoate (10)<smiles>COCC1C(/C=C/C(=O)OC)=C(C)C(=O)C1O</smiles>

To a cooled solution $\left(-78{ }^{\circ} \mathrm{C}\right)$ of LDA (1.65M in heptane/THF/ethylbenzene 2.8/1.9/1; $16.36 \mathrm{ml}, 27 \mathrm{mmol})$ in $20 \mathrm{ml}$ THF were added $4.97 \mathrm{~g}(27.0 \mathrm{mmol})$ of keto ester 7 dissolved in $60 \mathrm{ml}$ of THF over a period of $30 \mathrm{~min}$. The reaction mixture was stirred at $-78^{\circ} \mathrm{C}$ for $30 \mathrm{~min}$ before a solution of aldehyde $6^{\mathrm{S} 2}(3.75 \mathrm{~g}, 18.0 \mathrm{mmol})$ in $30 \mathrm{ml} \mathrm{THF}$ was added dropwise. After stirring for $60 \mathrm{~min}$ at $-78^{\circ} \mathrm{C}$, the temperature was raised to $0{ }^{\circ} \mathrm{C}$ over a period of $60 \mathrm{~min} .80 \mathrm{ml}$ of saturated $\mathrm{NH}_{4} \mathrm{Cl}$ solution were added and the mixture was diluted with $120 \mathrm{ml}$ of $\mathrm{Et}_{2} \mathrm{O}$. After phase separation the ethereal solution was dried over $\mathrm{Na}_{2} \mathrm{SO}_{4}$ and the solvent was removed under reduced pressure to provide a yellow oil. This material was purified by $\mathrm{FC}$ eluting with hexane/AcOEt $3 / 1$ to furnish $2.68 \mathrm{~g}(38 \%)$ of the desired $6 \mathrm{R}, 7 \mathrm{~S}$ isomer 10 . In addition, $1.91 \mathrm{~g}(27 \%)$ of the $6 \mathrm{~S}, 7 \mathrm{R}$ isomer (diastereomer 2$)$ were isolated.

$\mathbf{R}_{\mathbf{f}}\left(\right.$ Hexane/AcOEt 3/1): 0.19. $[\alpha]_{\mathbf{D}}^{25}:-8.51$ (c $\left.0.975, \mathrm{CHCl}_{3}\right)$.

${ }^{1} \mathrm{H}-\mathrm{NMR}\left(400 \mathrm{MHz}, \mathrm{CDCl}_{3}\right): \delta 0.92(\mathrm{~d}, \mathrm{~J}=6.89 \mathrm{~Hz}, 3 \mathrm{H}), 1.05(\mathrm{~d}, \mathrm{~J}=6.91 \mathrm{~Hz}, 3 \mathrm{H})$, $1.28(\mathrm{~s}, 6 \mathrm{H}), 1.84-1.76(\mathrm{~m}, 1 \mathrm{H}), 3.12-3.06(\mathrm{~m}, 1 \mathrm{H}), 3.38(\mathrm{~d}, \mathrm{~J}=2.85 \mathrm{~Hz}, 1 \mathrm{H}), 3.49-$ $3.44(\mathrm{~m}, 1 \mathrm{H}), 3.60-3.51(\mathrm{~m}, 2 \mathrm{H}), 3.74(\mathrm{~s}, 3 \mathrm{H}), 3.79(\mathrm{~s}, 3 \mathrm{H}), 4.47-4.39(\mathrm{~m}, 2 \mathrm{H}), 5.91$ 
$(d, J=15.97 \mathrm{~Hz}, 1 \mathrm{H}), 6.86(\mathrm{~d}, J=8.68 \mathrm{~Hz}, 2 \mathrm{H}), 7.06(\mathrm{~d}, J=15.97 \mathrm{~Hz}, 1 \mathrm{H}), 7.23(\mathrm{~d}, J$ $=8.68 \mathrm{~Hz}, 2 \mathrm{H}$ ).

${ }^{13} \mathrm{C}$-NMR $\left(100 \mathrm{MHz}, \mathrm{CDCl}_{3}\right): \delta 11.0,14.3,23.3,23.4,36.0,42.7,51.3,51.7,55.2$, 72.6, 72.9, 73.7, $113.7(2 \mathrm{CH}), 120.7,129.2(2 \mathrm{CH}), 130.3,150.9,159.1,166.4,215.7$.

HRMS (ESI): $415.2091\left[\mathrm{M}+\mathrm{Na}^{+}\right]$; calcd for $\left[\mathrm{C}_{22} \mathrm{H}_{32} \mathrm{O}_{6}+\mathrm{Na}\right] 415.2085$.

IR [ATR, neat]: $v\left(\mathrm{~cm}^{-1}\right) 3508,2967,2937,2875,1723,1701,1512,1245,1173$, 1082, 1032, 983, 819.

\section{Diastereomer 2:}

$\mathbf{R}_{\mathbf{f}}($ Hexane/AcOEt 3/1): 0.15 .

${ }^{1} \mathrm{H}-\mathrm{NMR}\left(400 \mathrm{MHz}, \mathrm{CDCl}_{3}\right): \delta 0.99(\mathrm{~d}, \mathrm{~J}=6.84 \mathrm{~Hz}, 3 \mathrm{H}), 1.11(\mathrm{~d}, J=6.68 \mathrm{~Hz}, 3 \mathrm{H})$, $1.29(\mathrm{~s}, 6 \mathrm{H}), 1.71-1.64(\mathrm{~m}, 1 \mathrm{H}), 3.08(\mathrm{~b}, 1 \mathrm{H}), 3.20-3.13(\mathrm{~m}, 1 \mathrm{H}), 3.40-3.34(\mathrm{~m}, 1 \mathrm{H})$, 3.49-3.45 (m, 2H), $3.76(\mathrm{~s}, 3 \mathrm{H}), 3.82(\mathrm{~s}, 3 \mathrm{H}), 4.47-4.38(\mathrm{~m}, 2 \mathrm{H}), 5.92(\mathrm{~d}, \mathrm{~J}=17.33$ $\mathrm{Hz}, 1 \mathrm{H}), 6.89(\mathrm{~d}, \mathrm{~J}=9.33 \mathrm{~Hz}, 2 \mathrm{H}), 7.05(\mathrm{~d}, \mathrm{~J}=16.66 \mathrm{~Hz}, 1 \mathrm{H}), 7.24(\mathrm{~d}, \mathrm{~J}=9.33 \mathrm{~Hz}, 2$ $\mathrm{H})$.

(6R,7S,8S)-Methyl 7-(tert-butyldimethylsilyloxy)-9-hydroxy-4,4,6,8-tetramethyl-5oxononanoate (11)

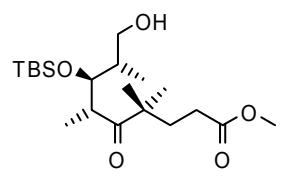

A. (6R,7S,8S,E)-methyl 7-(tert-butyldimethylsilyloxy)-9-(4-methoxybenzyloxy)4,4,6,8-tetramethyl-5-oxonon-2-enoate

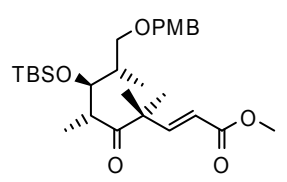

To a cooled solution $\left(-78{ }^{\circ} \mathrm{C}\right)$ of alcohol 10 and 2,6-lutidine in $\mathrm{CH}_{2} \mathrm{Cl}_{2}$ were added $2.27 \mathrm{~g}(8.59 \mathrm{mmol})$ of TBSOTf in $15 \mathrm{ml}$ of $\mathrm{CH}_{2} \mathrm{Cl}_{2}$. After $15 \mathrm{~min}$ at $-78{ }^{\circ} \mathrm{C}$, the mixture was stirred at r.t. for $60 \mathrm{~min}$. $30 \mathrm{ml}$ of sat. $\mathrm{NaHCO}_{3}$ solution were then added, the mixture was extracted with $\mathrm{CH}_{2} \mathrm{Cl}_{2}(3 \times 30 \mathrm{ml})$ and the combined organic extracts were dried over $\mathrm{Na}_{2} \mathrm{SO}_{4}$. The solvent was removed in vacuo and the residue was purified by FC (hexane/AcOEt 3/1) to give $2.40 \mathrm{~g}(94 \%)$ of 7-OTBS-10.

$\mathbf{R}_{\mathbf{f}}$ (Hexane/AcOEt 3/1): 0.64. [ $\left.\alpha\right]_{\mathrm{D}}{ }^{25}:-24.42$ (c $0.872, \mathrm{CHCl}_{3}$ ).

${ }^{1} \mathrm{H}$-NMR $\left(400 \mathrm{MHz}, \mathrm{CDCl}_{3}\right): \delta 0.05(\mathrm{~d}, \mathrm{~J}=1.81 \mathrm{~Hz}, 6 \mathrm{H}), 0.88(\mathrm{~s}, 9 \mathrm{H}), 0.94(\mathrm{~d}, \mathrm{~J}=$ $7.02 \mathrm{~Hz}, 3 \mathrm{H}), 1.01(\mathrm{~d}, \mathrm{~J}=7.02 \mathrm{~Hz}, 3 \mathrm{H}), 1.25(\mathrm{~s}, 6 \mathrm{H}), 1.76-1.67(\mathrm{~m}, 1 \mathrm{H}), 3.15-3.10$ $(\mathrm{m}, 1 \mathrm{H}), 3.32-3.24(\mathrm{~m}, 1 \mathrm{H}), 3.55-3.49(\mathrm{~m}, 1 \mathrm{H}), 3.74(\mathrm{~s}, 3 \mathrm{H}), 3.81(\mathrm{~s}, 3 \mathrm{H}), 3.98-3.83$ $(\mathrm{m}, 1 \mathrm{H}), 4.43-4.36(\mathrm{~m}, 2 \mathrm{H}), 5.85(\mathrm{~d}, \mathrm{~J}=15.98 \mathrm{~Hz}, 1 \mathrm{H}), 6.87(\mathrm{~d}, \mathrm{~J}=8.67 \mathrm{~Hz}, 2 \mathrm{H}), 7.13$ (d, J $=15.98 \mathrm{~Hz}, 1 \mathrm{H}), 7.24$ (d, J = 8.65 Hz, 2H).

${ }^{13} \mathrm{C}$-NMR $\left(100 \mathrm{MHz}, \mathrm{CDCl}_{3}\right): \delta-3.4,-3.3,16.4,16.6,18.8,24.1,24.4,26.5\left(3 \mathrm{CH}_{3}\right)$, $39.3,46.5,51.4,52.0,55.6,71.8,73.1,76.4,114.0(2 \mathrm{CH}), 120.3,129.6(2 \mathrm{CH})$, $131.1,152.4,159.4,167.1,214.8$. 
HRMS (ESI): $529.2959\left[\mathrm{M}+\mathrm{Na}^{+}\right]$; calcd for $\left[\mathrm{C}_{28} \mathrm{H}_{46} \mathrm{O}_{6} \mathrm{Si}+\mathrm{Na}\right] 529.2956$.

IR [ATR, neat]: $v\left(\mathrm{~cm}^{-1}\right) 2952,2932,2883,2856,1725,1512,1247,1173,1082$, $1036,988,870,832,774$.

B. (6R,7S,8S)-Methyl 7-(tert-butyldimethylsilyloxy)-9-(4-methoxybenzyloxy)-4,4,6,8tetramethyl-5-oxononanoate

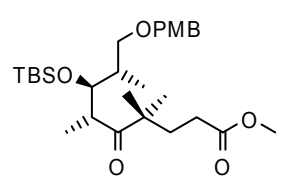

To a solution of $2.39 \mathrm{~g}(4.72 \mathrm{mmol})$ of the above 7-OTBS-10 in $50 \mathrm{ml}$ of $\mathrm{MeOH}$ were added $251 \mathrm{mg}$ of $\mathrm{Pd} / \mathrm{C}$ ( $5 \mathrm{~mol}-\%)$. The mixture was evacuated three times and then flooded with hydrogen. After stirring for $2.5 \mathrm{~h}$, additional $252 \mathrm{mg}$ of catalyst (5 mol-\%) were added and the reaction was complete after $18 \mathrm{~h}$. The mixture was filtered over a pad of Celite to remove the catalyst and after FC (hexane/AcOEt 5/1) the saturated product was isolated as a colorless oil in $95 \%$ yield $(2.28 \mathrm{~g})$.

Note: Hydrogenation under these conditions did not lead to any PMB-deprotected material.

$\mathbf{R}_{\mathbf{f}}$ (Hexane/AcOEt 3/1): 0.41. [ $\left.\alpha\right]_{\mathbf{D}}{ }^{25}:-17.49$ (c 0.846, $\left.\mathrm{CHCl}_{3}\right)$.

${ }^{1} \mathrm{H}$-NMR $\left(400 \mathrm{MHz}, \mathrm{CDCl}_{3}\right): \delta 0.07(\mathrm{~d}, \mathrm{~J}=2.01 \mathrm{~Hz}, 6 \mathrm{H}), 0.90(\mathrm{~s}, 9 \mathrm{H}), 0.97(\mathrm{~d}, \mathrm{~J}=7.03$ $\mathrm{Hz}, 3 \mathrm{H}), 1.04(\mathrm{~d}, \mathrm{~J}=6.89 \mathrm{~Hz}, 3 \mathrm{H}), 1.08(\mathrm{~s}, 3 \mathrm{H}), 1.12(\mathrm{~s}, 3 \mathrm{H}), 1.73-1.66(\mathrm{~m}, 1 \mathrm{H}), 1.92-$ $1.74(\mathrm{~m}, 2 \mathrm{H}), 2.24-2.71(\mathrm{~m}, 2 \mathrm{H}), 3.20-3.14(\mathrm{~m}, 1 \mathrm{H}), 3.38-3.29(\mathrm{~m}, 1 \mathrm{H}), 3.56-3.54(\mathrm{~m}$, $1 \mathrm{H}), 3.66(\mathrm{~s}, 3 \mathrm{H}), 3.81(\mathrm{~s}, 3 \mathrm{H}), 3.87-3.84(\mathrm{~m}, 1 \mathrm{H}), 4.39(\mathrm{~s}, 2 \mathrm{H}), 6.87(\mathrm{~d}, \mathrm{~J}=8.65 \mathrm{~Hz}$, $2 \mathrm{H}), 7.24(\mathrm{~d}, \mathrm{~J}=8.65 \mathrm{~Hz}, 2 \mathrm{H})$.

${ }^{13}$ C-NMR $\left(100 \mathrm{MHz}, \mathrm{CDCl}_{3}\right): \delta-3.4,-3.3,16.6,16.9,18.9,24.5,24.8,26.6\left(3 \mathrm{CH}_{3}\right)$, $30.1,34.5,39.2,45.2,47.9,51.9,55.6,71.9,73.2,114.0(2 \mathrm{CH}), 129.6(2 \mathrm{CH}), 131.1$, 159.4, 174.4, 217.0.

HRMS (ESI): $531.3121\left[\mathrm{M}+\mathrm{Na}^{+}\right]$; calcd for $\left[\mathrm{C}_{28} \mathrm{H}_{48} \mathrm{O}_{6} \mathrm{Si}+\mathrm{Na}^{+}\right] 531.3112$.

IR [ATR, neat]: $v\left(\mathrm{~cm}^{-1}\right)$ 2953, 2932, 2883, 2856, 1739, 1693, 1512, 1247, 1036, 831, 773.

C. (6R,7S,8S)-Methyl 7-(tert-butyldimethylsilyloxy)-9-hydroxy-4,4,6,8-tetramethyl-5oxononanoate (11)<smiles>COC(=O)CCC1(C)C(=O)C(C)[C@H](O)C1CO</smiles>

To a solution of the above hydrogenation product $(2.95 \mathrm{~g}, 5.80 \mathrm{mmol})$ in $\mathrm{CH}_{2} \mathrm{Cl}_{2}$ (14 $\mathrm{ml})$ and water $(1.4 \mathrm{ml})$ were added $1.44 \mathrm{~g}(6.38 \mathrm{mmol})$ of DDQ. After $1 \mathrm{~h}, 15 \mathrm{ml}$ of saturated $\mathrm{NaHCO}_{3}$ were added and after extraction with $\mathrm{CH}_{2} \mathrm{Cl}_{2}(3 \times 50 \mathrm{ml})$ and drying over $\mathrm{Na}_{2} \mathrm{SO}_{4}$ the solvent was removed under reduced pressure. Purification by $\mathrm{FC}$ (toluene/ $\mathrm{Et}_{2} \mathrm{O}$ 10/1) gave $1.66 \mathrm{~g}(74 \%)$ of the target product 11.

$\mathbf{R}_{\mathbf{f}}$ (Hexane/AcOEt 3/1): 0.27. [ $\left.\alpha\right]_{\mathbf{D}}{ }^{25}:+9.87$ (c $0.127, \mathrm{CHCl}_{3}$ ). 
${ }^{1} \mathrm{H}-\mathrm{NMR}\left(400 \mathrm{MHz}, \mathrm{CDCl}_{3}\right): \delta 0.12(\mathrm{~d}, \mathrm{~J}=8.98 \mathrm{~Hz}, 6 \mathrm{H}), 0.93(\mathrm{~s}, 9 \mathrm{H}), 0.99(\mathrm{~d}, \mathrm{~J}=$ $6.99 \mathrm{~Hz}, 3 \mathrm{H}), 1.10(\mathrm{~d}, \mathrm{~J}=6.93 \mathrm{~Hz}, 3 \mathrm{H}), 1.16(\mathrm{~s}, 3 \mathrm{H}), 1.20(\mathrm{~s}, 3 \mathrm{H}), 1.65-1.55(\mathrm{~m}, 1 \mathrm{H})$, 1.95-1.77 (m, 2H), $2.24(\mathrm{t}, \mathrm{J}=8.49 \mathrm{~Hz}, 2 \mathrm{H}), 2.42(\mathrm{t}, \mathrm{J}=6.2 \mathrm{~Hz}, 1 \mathrm{H}(\mathrm{OH})) 3.33-3.25$ $(\mathrm{m}, 1 \mathrm{H}), 3.56-3.45(\mathrm{~m}, 1 \mathrm{H}), 3.66-3.62(\mathrm{~m}, 1 \mathrm{H}), 3.67(\mathrm{~s}, 3 \mathrm{H}), 3.98-3.94(\mathrm{~m}, 1 \mathrm{H})$.

${ }^{13}$ C-NMR $\left(100 \mathrm{MHz}, \mathrm{CDCl}_{3}\right): \delta \quad-3.9,-3.6,15.6,16.6,18.4,24.3,24.8,26.2\left(3 \mathrm{CH}_{3}\right)$, 29.7, 34.2, 39.9, 45.5, 47.6, 51.7, 64.7, 77.9, 174.0, 218.3.

HRMS (ESI): $411.2524\left[\mathrm{M}+\mathrm{Na}^{+}\right]$; calc for $\left[\mathrm{C}_{20} \mathrm{H}_{40} \mathrm{O}_{5} \mathrm{Si}+\mathrm{Na}^{+}\right] 411.2524$.

IR [ATR, neat]: 3521, 2954, 2931, 2884, 2857, 1739, 1253, 1024, 835, 773.

(6R,7S,8S)-Methyl 7-(tert-butyldimethylsilyloxy)-4,4,6,8-tetramethyl-5-oxodec-9enoate (12)

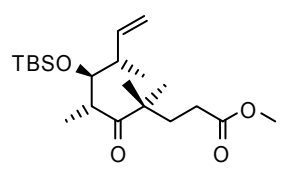

To a stirred solution of alcohol $11(0.47 \mathrm{~g}, 1.21 \mathrm{mmol})$ and powdered molecular sieves $(4 \AA)$ in $\mathrm{CH}_{2} \mathrm{Cl}_{2}$ was added NMO $(0.42 \mathrm{~g}, 3.14 \mathrm{mmol})$ followed by TPAP $(0.025$ $\mathrm{g}, 0.073 \mathrm{mmol}$ ) at r.t. After $1 \mathrm{~h}$ the mixture was filtered through a plug of silica, which was washed with AcOEt. After removal of the solvent under reduced pressure the crude aldehyde $\left(R_{f}\right.$ (Hexane/AcOEt 5/1): 0.30) was used directly in the subsequent Wittig reaction: To a solution of methyltriphenylphosphonium bromide $(0.56 \mathrm{~g}, 1.57$ $\mathrm{mmol})$ in THF $(7 \mathrm{ml})$ was added LiHMDS (1M in THF) dropwise at $0{ }^{\circ} \mathrm{C}$. After $30 \mathrm{~min}$ a solution of the crude aldehyde in $9 \mathrm{ml}$ of THF was slowly added and the mixture was stirred at $0{ }^{\circ} \mathrm{C}$ for $2 \mathrm{~h}$. $20 \mathrm{ml}$ of sat. aqu. $\mathrm{NH}_{4} \mathrm{Cl}$ and $30 \mathrm{ml}$ of water were then added and the mixture was extracted with $\mathrm{Et}_{2} \mathrm{O}(3 \times 50 \mathrm{ml})$. After drying of the combined $\mathrm{Et}_{2} \mathrm{O}$ extracts over $\mathrm{Na}_{2} \mathrm{SO}_{4}$ the solvent was removed under reduced pressure and the residue was purified by $\mathrm{FC}$ (hexane/Et $\mathrm{O}_{2} \mathrm{O} 1 / 100 \rightarrow 1 / 50$ ). Olefin 12 was obtained as a colorless oil ( $175 \mathrm{mg}, 38 \%$ over two steps).

Crude aldehyde: $\mathbf{R}_{\mathbf{f}}$ (Hexane/AcOEt 5/1): 0.30. ${ }^{1} \mathbf{H}-\mathrm{NMR}\left(400 \mathrm{MHz}, \mathrm{CDCl}_{3}\right): \delta 0.12$ (d, $\mathrm{J}=6.84 \mathrm{~Hz}, 6 \mathrm{H}), 0.91(\mathrm{~s}, 9 \mathrm{H}), 1.13(\mathrm{~d}, \mathrm{~J}=7.10 \mathrm{~Hz}, 3 \mathrm{H}), 1.14(\mathrm{~s}, 3 \mathrm{H}), 1.16(\mathrm{~d}, \mathrm{~J}=$ $7.10 \mathrm{~Hz} 1.21(\mathrm{~s}, 3 \mathrm{H}), 1.56(\mathrm{~s}, 1 \mathrm{H}), 1.95-1.77(\mathrm{~m}, 2 \mathrm{H}), 2.2-2.21(\mathrm{~m}, 2 \mathrm{H}), 3.29-3.21(\mathrm{~m}$, $1 \mathrm{H}), 3.67(\mathrm{~s}, 3 \mathrm{H}), 4.16-4.10(\mathrm{~m}, 1 \mathrm{H}), 9.72(\mathrm{~d}, \mathrm{~J}=2.09 \mathrm{~Hz}, 1 \mathrm{H}) . \mathrm{MS}\left(\mathrm{ES}^{+}\right): 409.26$ [M $\left.+\mathrm{Na}^{+}\right]$

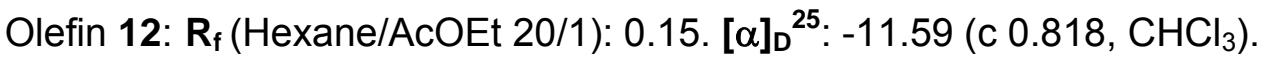

${ }^{1} \mathrm{H}-\mathrm{NMR}\left(400 \mathrm{MHz}_{\mathrm{CDCl}}\right.$ ): $\delta 0.09$ (s, 6H), $0.93(\mathrm{~s}, 9 \mathrm{H}), 1.04(\mathrm{~d}, \mathrm{~J}=2.54 \mathrm{~Hz}, 3 \mathrm{H})$, $1.05(\mathrm{~d}, \mathrm{~J}=2.5 \mathrm{~Hz}, 3 \mathrm{H}), 1.12(\mathrm{~s}, 3 \mathrm{H}), 1.17(\mathrm{~s}, 3 \mathrm{H}), 1.93-1.74(\mathrm{~m}, 2 \mathrm{H}), 2.08(\mathrm{t}, \mathrm{J}=$ 7.31, 1H), $2.23(\mathrm{t}, \mathrm{J}=8.38 \mathrm{~Hz}, 2 \mathrm{H}), 3.11-3.03(\mathrm{~m}, 1 \mathrm{H}), 3.91-3.87(\mathrm{~m}, 1 \mathrm{H}), 5.08-4.95$ $(\mathrm{m}, 2 \mathrm{H}), 5.69-5.85(\mathrm{~m}, 1 \mathrm{H})$.

${ }^{13}$ C-NMR $\left(100 \mathrm{MHz}, \mathrm{CDCl}_{3}\right): \delta$-3.5, -3.2, 16.5, 18.83, 18.84, 24.7, 25.2, $26.6\left(3 \mathrm{CH}_{3}\right)$, 30.1, 34.7, 43.9, 45.1, 47.6, 51.0, 76.8, 115.8, 140.1, 174.4, 217.0.

HRMS (ESI) : $407.2584\left[\mathrm{M}+\mathrm{Na}^{+}\right]$; calcd for $\left[\mathrm{C}_{21} \mathrm{H}_{40} \mathrm{O}_{4} \mathrm{Si}+\mathrm{Na}^{+}\right]$407.2588.

IR [ATR, neat]: 2954, 2931, 2885, 2857, 1742, 1696, 1254, 1043, 992, 871, 835, 774. 
(6R,7S,8S)-7-(tert-Butyldimethylsilyloxy)-4,4,6,8-tetramethyl-5-oxodec-9-enoic acid (4)<smiles>C=CC1=C(CCC(=O)O)C(=O)C(C)C1C(=O)O</smiles>

$\mathrm{LiOH}$ (19 mg, $0.78 \mathrm{mmol}, 6 \mathrm{eq})$ was added to a solution of methyl ester 12 (50 mg, $0.13 \mathrm{mmol}$ ) in $2.95 \mathrm{ml}$ of isopropanol and $0.74 \mathrm{ml}$ of water. The mixture was heated to $60{ }^{\circ} \mathrm{C}$ for $30 \mathrm{~min}$. It was then diluted with a mixture of $10 \mathrm{ml}$ of $\mathrm{CH}_{2} \mathrm{Cl}_{2}$ and $10 \mathrm{ml}$ of water and the $\mathrm{pH}$ was adjusted to $4-5$ with $1 \mathrm{~N} \mathrm{HCl}$. The aqueous phase was extracted three times with $\mathrm{CH}_{2} \mathrm{Cl}_{2}$ and after drying of the combined organic extracts over $\mathrm{Na}_{2} \mathrm{SO}_{4}$ the solvent was removed in vacuo. Acid 4 was obtained as a colorless oil, which could be used in the next step without further purification (47 mg, quant).

$\mathbf{R}_{\mathbf{f}}(\text { Hexane/AcOEt 5/2): 0.23. [ } \alpha]_{\mathbf{D}}{ }^{25}$ : -8.57 (c 0.7, $\mathrm{CHCl}_{3}$ ).

${ }^{1} \mathrm{H}-\mathrm{NMR}\left(400 \mathrm{MHz}, \mathrm{CDCl}_{3}\right): \delta 0.09(\mathrm{~s}, 6 \mathrm{H}), 0.93(\mathrm{~s}, 9 \mathrm{H}), 1.07-1.02(\mathrm{~m}, 6 \mathrm{H}), 1.13(\mathrm{~s}$, $3 \mathrm{H}), 1.18(\mathrm{~s}, 3 \mathrm{H}), 1.93-1.74(\mathrm{~m}, 2 \mathrm{H}), 2.13-2.05(\mathrm{~m}, 1 \mathrm{H}) 2.28(\mathrm{t}, \mathrm{J}=8.10 \mathrm{~Hz}, 2 \mathrm{H})$, 3.11-3.03 (m, 1H), 3.92-3.86 (m, 1H), 5.08-4.95 (m, 2H), 5.93-5.85 (m, 1H).

${ }^{13} \mathrm{C}-\mathrm{NMR}\left(100 \mathrm{MHz}, \mathrm{CDCl}_{3}\right): \delta-3.8,-3.6,16.2,18.48,18.49,24.4,24.9,26.2\left(3 \mathrm{CH}_{3}\right)$, $29.7,34.0,43.5,45.0,47.4,76.5,115.4,139.8,179.5,218.3$.

HRMS (ESI): $369.2459\left[\mathrm{M}+\mathrm{H}^{+}\right]$; calcd for $\left[\mathrm{C}_{20} \mathrm{H}_{38} \mathrm{O}_{4} \mathrm{Si}+\mathrm{H}^{+}\right] 369.2467$.

IR [ATR, neat]: 2958 (s), 2932 (s), 2857 (m), 1709 (s), 1468 (m), 1254 (m), 1043 (m), 1001 (s), 837 (s), 775 (s).

\section{Synthesis of Building Block 5}

3-Amino-4-(methylamino)benzoic acid $(\mathbf{1 4})^{\mathrm{S3}}$

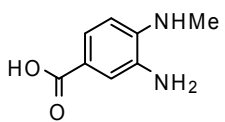

A. 4-(Methylamino)-3-nitrobenzoic acid<smiles>CNc1ccc(C(=O)O)cc1[N+](=O)[O-]</smiles>

Methylamine $(150 \mathrm{ml}$ of a $33 \%$ solution in $\mathrm{EtOH}, 1.5 \mathrm{~mol})$ was added to a solution of 4-fluoro-3-nitro-benzoic acid $(25.0 \mathrm{~g}, 135 \mathrm{mmol})$ in $\mathrm{MeOH}(350 \mathrm{ml})$ with vigorous stirring. After stirring at r.t. for $2 \mathrm{~h}$, water was added to the orange reaction mixture, the solution was cooled to $5{ }^{\circ} \mathrm{C}$ (ice bath) and the $\mathrm{pH}$ was adjusted to 5 by slow addition of $5 \mathrm{~N} \mathrm{HCl}$ (until the orange red color had turned to yellow). The precipitate formed was collected by filtration and washed with $2 \times 50 \mathrm{ml}$ of distilled water. Drying in vacuo for $18 \mathrm{~h}$ gave $(26.2 \mathrm{~g}, 99 \%)$ 4-methylamino-3-nitrobenzoic acid as a yellow solid. 
$\mathbf{R}_{\mathbf{f}}\left(\mathrm{CHCl}_{3} / \mathrm{MeOH}\right.$ 9/1): 0.30 .

${ }^{1} \mathrm{H}$-NMR (400 MHz, $\left.\left(\mathrm{CD}_{3}\right)_{2} \mathrm{SO}\right): \delta 3.00(\mathrm{~d}, \mathrm{~J}=5.0 \mathrm{~Hz}, 3 \mathrm{H}), 3.33(\mathrm{~b}, 1 \mathrm{H}), 7.04(\mathrm{~d}, \mathrm{~J}=$ $9.2 \mathrm{~Hz}, 1 \mathrm{H}), 7.97(\mathrm{dd}, J=9.2,1.9 \mathrm{~Hz}, 1 \mathrm{H}), 8.51-8.57(\mathrm{~m}, 1 \mathrm{H}), 8.6(\mathrm{~d}, \mathrm{~J}=1.9 \mathrm{~Hz}, 1 \mathrm{H})$, $12.84(\mathrm{~b}, 1 \mathrm{H})$.

${ }^{13}$ C-NMR $\left(100 \mathrm{MHz},\left(\mathrm{CD}_{3}\right)_{2} \mathrm{SO}\right): \delta 29.9,114.4,116.8,128.4,130.4,136.0,148.0$, 166.1 .

B. 3-Amino-4-(methylamino)benzoic acid (14)<smiles>CC1CC2CC1C(N(C)C)CC2O</smiles>

4-(Methylamino)-3-nitrobenzoic acid $(26.2 \mathrm{~g}, 0.133 \mathrm{~mol}$ ) was hydrogenated over Ra$\mathrm{Ni}$ in THF/EtOH 2/1 (1L) at $40{ }^{\circ} \mathrm{C}$ and atmospheric pressure. After $12 \mathrm{~h}$ the catalyst was removed by filtration and washed with THF/EtOH 2/1 $(250 \mathrm{ml})$. The combined filtrates were evaporated under reduced pressure to yield $22.0 \mathrm{~g} \mathrm{(99 \% )} \mathrm{of} \mathrm{3-amino-4-}$ (methylamino)-benzoic acid as a mauve solid. This material was used in the next step without further purification.

$\mathbf{R}_{\mathbf{f}}\left(\mathrm{CHCl}_{3} / \mathrm{MeOH}\right.$ 9/1): 0.21 .

${ }^{1} \mathrm{H}-\mathrm{NMR}\left(400 \mathrm{MHz},\left(\mathrm{CD}_{3}\right)_{2} \mathrm{SO}\right): \delta 2.76(\mathrm{~s}, 3 \mathrm{H}), 5.31(\mathrm{~b}, 1 \mathrm{H}), 6.37(\mathrm{~d}, \mathrm{~J}=8.3 \mathrm{~Hz}, 1 \mathrm{H})$, $7.14(\mathrm{~d}, \mathrm{~J}=2.0 \mathrm{~Hz}, 1 \mathrm{H}), 7.22$ (dd, $J=8.3,2.0 \mathrm{~Hz}$ ).

${ }^{13}$ C-NMR $\left(100 \mathrm{MHz},\left(\mathrm{CD}_{3}\right)_{2} \mathrm{SO}\right): \delta 29.7,107.3,114.3,117.8,120.9,134.0,141.3$, 168.1 .

MS (ESI): $167.05\left[\mathrm{M}+\mathrm{H}^{+}\right]$.

1,2-Dimethyl-1H-benzimidazole-5-carboxylic acid methyl ester (15)

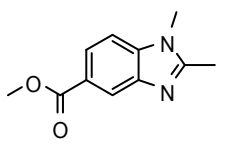

A. 1,2-Dimethyl-1H-benzo[d]imidazole-5-carboxylic acid ${ }^{\text {S4 }}$<smiles>Cc1cc2cc(O)ccn2n1</smiles>

To a suspension of crude acid $14(22.7 \mathrm{~g}, 137 \mathrm{mmol})$ in $\mathrm{MeOH}(0.75 \mathrm{~L})$ was added trimethylorthoacetate $(21 \mathrm{ml}, 164 \mathrm{mmol})$ and the mixture was refluxed. The starting material dissolved upon heating, while the product precipitated as the reaction proceeded. After $1 \mathrm{~h}$ at reflux, the mixture was carefully cooled to $0{ }^{\circ} \mathrm{C}$ and the precipitate was collected by filtration $(\sim 15 \mathrm{~g})$. The filtrate was then concentrated under reduced pressure to ca. one third of its volume, resulting in the precipitation of additional product. Drying of the combined precipitates gave $20.0 \mathrm{~g}(77 \%)$ of crude 
2,3-dimethyl benzimidazole-6-carboxylic acid as a blue solid that was used in the subsequent step without further purification.

$\mathbf{R}_{\mathbf{f}}\left(\mathrm{CHCl}_{3} / \mathrm{MeOH}\right.$ 9/1): 0.13.

${ }^{1} \mathrm{H}-\mathrm{NMR}\left(400 \mathrm{MHz},\left(\mathrm{CD}_{3}\right)_{2} \mathrm{SO}\right): \delta 2.55(\mathrm{~s}, 3 \mathrm{H}), 3.76(\mathrm{~s}, 3 \mathrm{H}), 7.55(\mathrm{~d}, \mathrm{~J}=8.5 \mathrm{~Hz}, 1 \mathrm{H})$, 7.82 (dd, $J=8.5,1.6 \mathrm{~Hz}, 1 \mathrm{H}), 8.09(\mathrm{~d}, \mathrm{~J}=1.6 \mathrm{~Hz}, 1 \mathrm{H}), 12.65(\mathrm{~b}, 1 \mathrm{H})$.

${ }^{13} \mathrm{C}-\mathrm{NMR}\left(100 \mathrm{MHz},\left(\mathrm{CD}_{3}\right)_{2} \mathrm{SO}\right): \delta 13.5,29.9,109.5,119.8,122.8,123.9,139.0$, $141.7,154.3,168.0$.

HRMS (ESI): $191.0815\left[\mathrm{M}+\mathrm{H}^{+}\right]$; calcd for $\left[\mathrm{C}_{10} \mathrm{H}_{10} \mathrm{~N}_{2} \mathrm{O}_{2}+\mathrm{H}^{+}\right] 191.0815$.

B. 1,2-Dimethyl-1H-benzimidazole-5-carboxylic acid methyl ester (15)<smiles>COC(=O)c1ccc2c(c1)nc(C)n2C</smiles>

Sulfuric acid $(20 \mathrm{ml}, 375 \mathrm{mmol})$ was carefully added to a suspension of 2,3-dimethyl benzimidazole-6-carboxylic acid $(20.0 \mathrm{~g}, 105 \mathrm{mmol})$ in $\mathrm{MeOH}(750 \mathrm{ml})$ at $0{ }^{\circ} \mathrm{C}$. The mixture was then refluxed for $5 \mathrm{~h}$ and the solvent was removed under reduced pressure. The dark brown residue was carefully dissolved in ice cold water $(500 \mathrm{ml})$ and the $\mathrm{pH}$ of the solution was adjusted to 9 by addition of $4 \mathrm{~N} \mathrm{NaOH}(\sim 190 \mathrm{ml})$, resulting in the precipitation of the product. The product was collected by filtration, washed twice with water $(50 \mathrm{ml})$ and then dried in high vacuum to furnish $20.2 \mathrm{~g}$ (94\%) of 1,2-dimethyl-1H-benzimidazole-5-carboxylic acid methyl ester as an offwhite solid.

$\mathbf{R}_{\mathbf{f}}\left(\mathrm{CHCl}_{3} / \mathrm{MeOH}\right.$ 9/1): 0.55 .

${ }^{1} \mathrm{H}-\mathrm{NMR}\left(400 \mathrm{MHz},\left(\mathrm{CD}_{3}\right)_{2} \mathrm{SO}\right): \delta 2.55(\mathrm{~s}, 3 \mathrm{H}), 3.76(\mathrm{~s}, 3 \mathrm{H}), 3.85$ (s, 3H), 7.57 (d, J = $8.5 \mathrm{~Hz}, 1 \mathrm{H}), 7.83(\mathrm{~d}, \mathrm{~J}=8.5 \mathrm{~Hz}, 1 \mathrm{H}), 8.12(\mathrm{~s}, 1 \mathrm{H})$.

${ }^{13}$ C-NMR (100 MHz, $\left.\left(\mathrm{CD}_{3}\right)_{2} \mathrm{SO}\right): \delta 13.5,29.9,51.9,109.7,119.7,122.56,122.65$, $139.2,141.8,154.6,166.9$.

HRMS (ESI): $205.0970\left[\mathrm{M}+\mathrm{H}^{+}\right]$; calcd for $\left[\mathrm{C}_{11} \mathrm{H}_{12} \mathrm{~N}_{2} \mathrm{O}_{2}+\mathrm{H}^{+}\right] 205.0972$.

1,2-Dimethyl-1H-benzo[d]imidazole-5-carbaldehyde (8)

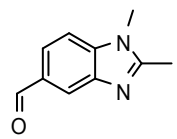

A. (1,2-Dimethyl-1H-benzo[d]imidazol-5-yl)methanol ${ }^{\mathrm{S} 5}$

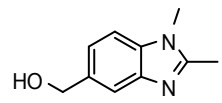

To a suspension of ester $15(20.2 \mathrm{~g}, 99 \mathrm{mmol})$ in THF $(800 \mathrm{ml})$ was added $\mathrm{LiAlH}_{4}$ (3.81 g, $100.5 \mathrm{mmol})$ in 10 portions at r.t. and under an Ar atmosphere. After completion of the addition, the mixture was stirred for $2 \mathrm{~h}$. (The starting material 
dissolved as the reaction proceeded). The reaction was then carefully (under a flow of $\mathrm{Ar}$ ) quenched by the successive slow addition of water $(3.9 \mathrm{ml}), 15 \%$ aqu. $\mathrm{NaOH}$ $(3.9 \mathrm{ml})$ and water $(11.7 \mathrm{ml})$. The mixture was stirred for another $15 \mathrm{~min}$ and the precipitate was removed by filtration and washed with THF $(50 \mathrm{ml})$ and $\mathrm{MeOH}(2 \mathrm{x}$ $100 \mathrm{ml}$ ). The combined filtrates were then evaporated under reduced pressure to give $16.4 \mathrm{~g}(94 \%)$ of the desired alcohol as a pink powder that was used in the next step without further purification.

$\mathbf{R}_{\mathbf{f}}\left(\mathrm{CHCl}_{3} / \mathrm{MeOH} 9 / 1\right): 0.20$.

${ }^{1} \mathrm{H}-\mathrm{NMR}\left(400 \mathrm{MHz}, \mathrm{CDCl}_{3}\right): \delta 2.20(\mathrm{br}, 1 \mathrm{H}), 2.61(\mathrm{~s}, 3 \mathrm{H}), 3.73(\mathrm{~s}, 3 \mathrm{H}), 4.79(\mathrm{~s}, 2 \mathrm{H})$, $7.26(\mathrm{~d}, \mathrm{~J}=8.3 \mathrm{~Hz}, 1 \mathrm{H}), 7.29(\mathrm{~d}, \mathrm{~J}=8.3,1.5 \mathrm{~Hz}, 1 \mathrm{H}), 7.65(\mathrm{~s}, 1 \mathrm{H})$.

${ }^{13} \mathrm{C}-\mathrm{NMR}\left(100 \mathrm{MHz},\left(\mathrm{CD}_{3}\right)_{2} \mathrm{SO}\right): \delta 13.4,29.6,63.5,109.0,116.2,120.5,134.9,135.6$, 142.2, 152.1.

HRMS (ESI): $177.1022\left[\mathrm{M}+\mathrm{H}^{+}\right]$; calcd for $\left[\mathrm{C}_{10} \mathrm{H}_{12} \mathrm{~N}_{2} \mathrm{O}+\mathrm{H}^{+}\right] 177.1022$.

B. 1,2-Dimethyl-1H-benzo[d]imidazole-5-carbaldehyde $(\mathbf{8})^{\mathrm{S5}}$

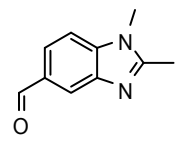

To a cooled solution $\left(-78{ }^{\circ} \mathrm{C}\right)$ of oxalyl chloride $(5.85 \mathrm{ml}, 68.05 \mathrm{mmol})$ in $\mathrm{CH}_{2} \mathrm{Cl}_{2}(160$ $\mathrm{ml})$ were added $10.07 \mathrm{ml}(143.7 \mathrm{mmol})$ of DMSO as a solution in $34 \mathrm{ml} \mathrm{CH}_{2} \mathrm{Cl}_{2}$ over a period of $\sim 5 \mathrm{~min}$. After 10 minutes of stirring at $-78{ }^{\circ} \mathrm{C}$ the above alcohol $(9.0 \mathrm{~g}, 51$ mmol) was added as a suspension in $330 \mathrm{ml}$ of $\mathrm{CH}_{2} \mathrm{Cl}_{2}$ over 5 min and stirring was continued for 2.5 h. $49.2 \mathrm{ml}$ of triethylamine were added to the mixture, which was subsequently warmed to $-10{ }^{\circ} \mathrm{C}$. After the addition of $340 \mathrm{ml}$ of water and additional $200 \mathrm{ml}$ of $\mathrm{CH}_{2} \mathrm{Cl}_{2}$ the mixture was washed with brine $(100 \mathrm{ml})$ and the combined aqueous phases were extracted with $\mathrm{CH}_{2} \mathrm{Cl}_{2}(3 \times 75 \mathrm{ml})$. After separation of the phases and drying over $\mathrm{MgSO}_{4}$ the solvent was removed under reduced pressure. The resulting crude product was purified via $\mathrm{FC}$, eluting with $\mathrm{CH}_{2} \mathrm{Cl}_{2}$ /acetone 1/1. Aldehyde 8 was obtained as a light yellow solid $(8.1 \mathrm{~g}, 91 \%)$.

$\mathbf{R}_{\mathbf{f}}\left(\mathrm{CHCl}_{3} / \mathrm{MeOH}\right.$ 9/1): 0.43 .

${ }^{1} \mathrm{H}-N M R\left(400 \mathrm{MHz}, \mathrm{CDCl}_{3}\right): \delta 2.59(\mathrm{~s}, 3 \mathrm{H}), 3.71(\mathrm{~s}, 3 \mathrm{H}), 7.31(\mathrm{~d}, \mathrm{~J}=8.3 \mathrm{~Hz}, 1 \mathrm{H}), 7.76$ (dd, $J=8.3,1.3 \mathrm{~Hz}, 1 \mathrm{H}), 8.10(\mathrm{~m}, 1 \mathrm{H}), 10.00(\mathrm{~s}, 1 \mathrm{H})$.

${ }^{13} \mathrm{C}-\mathrm{NMR}\left(100 \mathrm{MHz}, \mathrm{CDCl}_{3}\right): \delta 13.9,30.1,109.4,122.6,122.9,131.3,140.1,142.4$, 154.3, 192.1.

HRMS (ESI): $175.0865\left[\mathrm{M}+\mathrm{H}^{+}\right]$; calcd for $\left[\mathrm{C}_{10} \mathrm{H}_{10} \mathrm{~N}_{2} \mathrm{O}+\mathrm{H}^{+}\right] 175.0866$.

IR [ATR, neat]: 2802 (w), 2721 (w), 1685 (s), 1608 (s), 1580 (m), 1329 (m), 1285 (s), $808(\mathrm{~m}), 721(\mathrm{~m})$.

(S)-5-(1-(tert-Butyldimethylsilyloxy)but-3-enyl)-1,2-dimethyl-1H-benzo[d]imidazole (16)

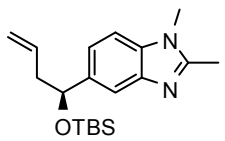


A. (S)-1-(1,2-Dimethyl-1H-benzo[d]imidazol-5-yl)but-3-en-1-ol

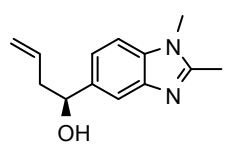

To a solution of (-)-DIP-Cl $(18.78 \mathrm{~g}, 58.55 \mathrm{mmol})$ in $125 \mathrm{ml}$ of dry $\mathrm{Et}_{2} \mathrm{O}$ were added $58.6 \mathrm{ml}(58.55 \mathrm{mmol})$ of allyl magnesium bromide ( $1 \mathrm{M}$ solution in $\left.\mathrm{Et}_{2} \mathrm{O}\right)$. After stirring at r.t. for $1 \mathrm{~h}, 80 \mathrm{ml}$ of hexane were added to the solution and the formed precipitate was removed by filtration under Ar. After washing with hexane $(2 \times 25 \mathrm{ml})$, the filtrate was cooled to $-78{ }^{\circ} \mathrm{C}$. In a second flask $6.0 \mathrm{~g}(34.44 \mathrm{mmol})$ of aldehyde 8 were suspended in $125 \mathrm{ml}$ of $\mathrm{Et}_{2} \mathrm{O}$ and cooled to $-100^{\circ} \mathrm{C}$. The cooled borane solution was slowly added to this suspension via cannula and the solution was stirred at $-100{ }^{\circ} \mathrm{C}$ for $90 \mathrm{~min}$ after the addition was complete. Then $11 \mathrm{ml}$ of dry $\mathrm{MeOH}$ were added and the mixture was warmed to $10^{\circ} \mathrm{C}$. After the addition of $21.5 \mathrm{ml}$ of ethanolamine the mixture was left stirring overnight. The $\mathrm{pH}$ was adjusted to 8 with water and saturated aqu. $\mathrm{NH}_{4} \mathrm{Cl}$ and the aqueous solution was extracted with $\mathrm{CH}_{2} \mathrm{Cl}_{2}(3 \times 75 \mathrm{ml})$. The combined organic extracts were then dried over $\mathrm{MgSO}_{4}$ and the solvent was removed under reduced pressure. After $\mathrm{FC}$ with $\mathrm{CH}_{2} \mathrm{Cl}_{2} / \mathrm{MeOH} 15 / 1$ the desired homoallylic alcohol was obtained as a white solid $(4.75 \mathrm{~g}, 64 \%$, ee $91 \%$ determined by MTPA ester analysis).

$\mathbf{R}_{\mathbf{f}}\left(\mathrm{CH}_{2} \mathrm{Cl}_{2} / \mathrm{MeOH} 15 / 1\right): 0.13$. Mp.: $123-124^{\circ} \mathrm{C} .[\alpha]_{\mathrm{D}}{ }^{25}:-46.5$ (c $\left.0.94, \mathrm{CHCl}_{3}\right)$.

${ }^{1} \mathrm{H}-\mathrm{NMR}\left(400 \mathrm{MHz}, \mathrm{CDCl}_{3}\right): \delta$ 2.54-2.58 (m, 2H), $2.58(\mathrm{~s}, 3 \mathrm{H}), 3.70(\mathrm{~s}, 3 \mathrm{H}), 4.84(\mathrm{t}, \mathrm{J}$ $=6.6 \mathrm{~Hz}, 1 \mathrm{H}), 5.07-5.17(\mathrm{~m}, 2 \mathrm{H}), 5.75-5.87(\mathrm{~m}, 1 \mathrm{H}), 7.23(\mathrm{~d}, \mathrm{~J}=8.1 \mathrm{~Hz}, 1 \mathrm{H}), 7.28$ $(\mathrm{m}, 2 \mathrm{H}), 7.63(\mathrm{~s}, 1 \mathrm{H})$.

${ }^{13}$ C-NMR $\left(100 \mathrm{MHz}, \mathrm{CDCl}_{3}\right): \delta 13.8,29.9,44.1,73.9,108.7,116.4,117.9,120.2$, 134.8, 135.3, 138.1, 142.5, 152.3.

HRMS (ESI): $217.1336\left[\mathrm{M}+\mathrm{H}^{+}\right]$; calcd for $\left[\mathrm{C}_{13} \mathrm{H}_{16} \mathrm{~N}_{2} \mathrm{O}+\mathrm{H}^{+}\right] 217.1335$.

IR [ATR, neat]: 3196 (b), 3074 (m), 2929 (m), 2361 (s), 2340 (s), 1640 (w), 1519 (s), 1433 (s), 1399 (s), 1326 (s), 1246 (m), 1053 (m), 805 (m), 672 (m).

B. (S)-5-(1-(tert-Butyldimethylsilyloxy)but-3-enyl)-1,2-dimethyl-1H-benzo[d]imidazole (16)

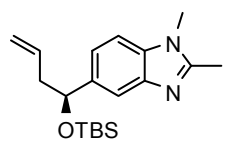

A solution of the above homoallylic alcohol $(7.0 \mathrm{~g}, 32 \mathrm{mmol})$ in $35 \mathrm{ml}$ DMF was cooled to $0{ }^{\circ} \mathrm{C}$. After addition of imidazole $(3.3 \mathrm{~g}, 49 \mathrm{mmol}), 5.85 \mathrm{~g}(39 \mathrm{mmol})$ of TBS-Cl were added to the solution in portions. The mixture was warmed to r.t. and stirred for $5 \mathrm{~h}$. After addition of $\mathrm{MeOH}$ (ca. $2 \mathrm{ml}$ ) the solvent was removed under reduced pressure and the residue was taken up with AcOEt/water and washed with AcOEt $(3 \times 50 \mathrm{ml})$. The combined organic phases were dried over $\mathrm{MgSO}_{4}$ and the solvent was removed under reduced pressure. After $\mathrm{FC}$ with $\mathrm{CH}_{2} \mathrm{Cl}_{2} / \mathrm{MeOH} 30 / 1$ protected alcohol 16 was obtained as a soft white solid (10.05 g, 95\%). 
$\mathbf{R}_{\mathbf{f}}\left(\mathrm{CH}_{2} \mathrm{Cl}_{2} / \mathrm{MeOH}\right.$ 20/1): 0.43. Mp.: $56^{\circ} \mathrm{C}$. $[\alpha]_{\mathbf{D}}{ }^{25}:-40.9$ (c 4.15, $\left.\mathrm{CHCl}_{3}\right)$.

${ }^{1} \mathrm{H}-\mathrm{NMR}\left(400 \mathrm{MHz}, \mathrm{CDCl}_{3}\right): \delta-0.16(\mathrm{~s}, 3 \mathrm{H}), 0.02(\mathrm{~s}, 3 \mathrm{H}), 0.87(\mathrm{~s}, 9 \mathrm{H}), 2.37-2.45(\mathrm{~m}$, $1 \mathrm{H}), 2.47-2.55(\mathrm{~m}, 1 \mathrm{H}), 2.58(\mathrm{~s}, 3 \mathrm{H}), 3.69(\mathrm{~s}, 3 \mathrm{H}), 4.77-4.80(\mathrm{~m}, 1 \mathrm{H}), 4.95-5.02(\mathrm{~m}$, $2 \mathrm{H}), 5.72-5.83(\mathrm{~m}, 1 \mathrm{H}), 7.18-7.23(\mathrm{~m}, 2 \mathrm{H}), 7.58(\mathrm{~s}, 1 \mathrm{H})$.

${ }^{13} \mathrm{C}-\mathrm{NMR}\left(100 \mathrm{MHz}, \mathrm{CDCl}_{3}\right): \delta-4.9,-4.6,13.8,18.3,25.9\left(3 \mathrm{CH}_{3}\right), 29.9,46.0,75.4$, $108.3,116.4,116.6,120.3,135.0,135.5,139.2,142.4,151.9$.

HRMS (ESI): $331.2194\left[\mathrm{M}+\mathrm{H}^{+}\right]$; calcd for $\left[\mathrm{C}_{19} \mathrm{H}_{30} \mathrm{~N}_{2} \mathrm{OSi}+\mathrm{H}^{+}\right] 331.2200$.

IR [ATR, neat]: $2930(\mathrm{~m}), 2856(\mathrm{~m}), 1519(\mathrm{~m}), 1431(\mathrm{~m}), 1397(\mathrm{~m}), 1248(\mathrm{~s}), 832$ (s), $775(\mathrm{~s})$.

(S,E)-5-(tert-Butyldimethylsilyloxy)-5-(1,2-dimethyl-1H-benzo[d]imidazol-5-yl)pent-2en-1-ol (17)

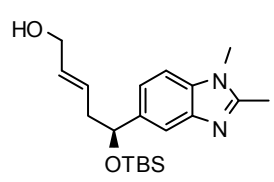

A. (S)-3-(tert-Butyldimethylsilyloxy)-3-(1,2-dimethyl-1H-benzo[d]imidazol-5yl)propanal

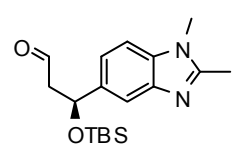

Ozone was bubbled through a solution of olefin $16(6.34 \mathrm{~g}, 19.18 \mathrm{mmol})$ in $\mathrm{MeOH}$ (70 $\mathrm{ml})$ and $\mathrm{CH}_{2} \mathrm{Cl}_{2}(70 \mathrm{ml})$ for ca. 60 min until most of the starting material was consumed (as assessed by TLC). To remove remaining ozone, nitrogen was subsequently bubbled through the solution for $15 \mathrm{~min}$ followed by the addition of $\mathrm{Me}_{2} \mathrm{~S}(7 \mathrm{ml})$. After slow warming to r.t., $100 \mathrm{ml}$ of sat. aqu. $\mathrm{NaHCO}_{3}$ were added and the mixture was extracted with $\mathrm{CH}_{2} \mathrm{Cl}_{2}(3 \times 50 \mathrm{ml})$. The combined organic extracts were dried over $\mathrm{MgSO}_{4}$ and the solvent was removed under reduced pressure. As storage of the aldehyde led to decomposition via elimination of $\mathrm{TBS}-\mathrm{OH}$ and formation of a completely conjugated $\pi$-electron system, the material obtained after extraction and evaporation ( $\sim 5 \mathrm{~g})$ was only purified by filtration through a plug of silica and then directly used in the subsequent Wittig reaction.

$\mathbf{R}_{\mathbf{f}}\left(\mathrm{CH}_{2} \mathrm{Cl}_{2} / \mathrm{MeOH} 20 / 1\right): 0.25$.

${ }^{1} \mathrm{H}-\mathrm{NMR}\left(400 \mathrm{MHz}, \mathrm{CDCl}_{3}\right): \delta-0.18(\mathrm{~s}, 3 \mathrm{H}), 0.04(\mathrm{~s}, 3 \mathrm{H}), 0.85$ (s, 3H), 2.57-2.60 (m, $4 \mathrm{H}), 2.86-2.95(\mathrm{~m}, 1 \mathrm{H}), 3.71(\mathrm{~s}, 3 \mathrm{H}), 5.32(\mathrm{dd}, \mathrm{J}=8.1,4.2 \mathrm{~Hz}, 1 \mathrm{H}), 7.23-7.24(\mathrm{~m}$, $2 \mathrm{H}), 7.64(\mathrm{~s}, 1 \mathrm{H}), 9.80(\mathrm{t}, \mathrm{J}=2.3 \mathrm{~Hz}, 1 \mathrm{H})$.

${ }^{13} \mathrm{C}-\mathrm{NMR}\left(100 \mathrm{MHz}, \mathrm{CDCl}_{3}\right): \delta-5.14,-4.54,13.85,18.09,25.75\left(3 \mathrm{CH}_{3}\right), 29.94,54.50$, 71.21, 108.81, 116.20, 119.94, 135.38, 137.80, 143.57, 152.41, 201.71.

HRMS (ESI): $333.1993\left[\mathrm{M}+\mathrm{H}^{+}\right]$; calcd for $\left[\mathrm{C}_{18} \mathrm{H}_{28} \mathrm{~N}_{2} \mathrm{O}_{2} \mathrm{Si}+\mathrm{H}^{+}\right] 333.1993$. 
B. $(S, E)$-ethyl 5-(tert-Butyldimethylsilyloxy)-5-(1,2-dimethyl-1H-benzo[d]imidazol-5yl)pent-2-enoate

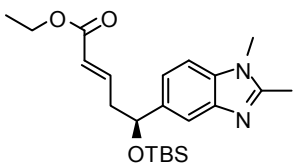

To a solution of $4.37 \mathrm{~g}(13.13 \mathrm{mmol})$ of the above crude aldehyde in $25 \mathrm{ml}$ of $\mathrm{CH}_{2} \mathrm{Cl}_{2}$ were added $5.49 \mathrm{~g}(15.76 \mathrm{mmol})$ of $\mathrm{Ph}_{3} \mathrm{PCHCO}_{2} \mathrm{Et}$ and the mixture was stirred at r.t. for $18 \mathrm{~h}$. Filtration of the mixture through a plug of silica $\left(\mathrm{CH}_{2} \mathrm{Cl}_{2} / \mathrm{MeOH} 50 / 1\right)$ and evaporation of solvent gave the crude enoate. Purification of this material by FC did not allow removal of triphenylphosphine oxide; as the subsequent step was not affected by the presence of triphenylphosphine oxide and in order to avoid unnecessary loss of material, the contaminated enoate was as such used in the next step.

${ }^{1} \mathrm{H}-\mathrm{NMR}\left(400 \mathrm{MHz}, \mathrm{CDCl}_{3}\right): \delta-0.17(\mathrm{~s}, 3 \mathrm{H}),-0.01(\mathrm{~s}, 3 \mathrm{H}), 0.87(\mathrm{~s}, 9 \mathrm{H}), 1.26(\mathrm{t}, \mathrm{J}=$ 7.0, 3H), 2.50-2.58 (m, 1H), $2.58(\mathrm{~s}, 3 \mathrm{H}), 2.58-2.67(\mathrm{~m}, 1 \mathrm{H}), 3.71(\mathrm{~s}, 3 \mathrm{H}), 4.16(\mathrm{q}, \mathrm{J}=$ $7.0 \mathrm{~Hz}, 2 \mathrm{H}), 4.87(\mathrm{dd}, J=4.8,7.5 \mathrm{~Hz}, 1 \mathrm{H}), 5.80(\mathrm{~d}, J=15.6 \mathrm{~Hz}, 1 \mathrm{H}), 6.97$ (dt, $J=$ 15.6, 7.5 Hz, 1H), $7.21(\mathrm{~s}, 2 \mathrm{H}), 7.59(\mathrm{~s}, 1 \mathrm{H})$.

${ }^{13} \mathrm{C}$-NMR $\left(100 \mathrm{MHz}, \mathrm{CDCl}_{3}\right): \delta-5.0,-4.6,13.9,14.3,18.2,25.8,29.9,44.4,60.1$, $74.6,108.6,116.2,120.0,123.3,135.2,138.6,142.5,145.9,152.2,166.4$.

C. (S,E)-5-(tert-Butyldimethylsilyloxy)-5-(1,2-dimethyl-1H-benzo[d]imidazol-5-yl)pent2-en-1-ol (17)

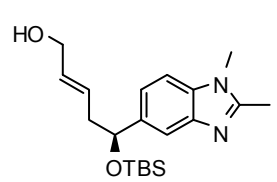

To a solution of $5.29 \mathrm{~g}(13.13 \mathrm{mmol})$ of the above crude enoate in $95 \mathrm{ml}$ of $\mathrm{CH}_{2} \mathrm{Cl}_{2}$ were slowly added $31.5 \mathrm{ml}(31.51 \mathrm{mmol})$ of a $1 \mathrm{M}$ DIBAL-H solution in $\mathrm{CH}_{2} \mathrm{Cl}_{2}$ at -78 ${ }^{\circ} \mathrm{C}$. The reaction mixture was left to stir at $-78{ }^{\circ} \mathrm{C}$ for $1.5 \mathrm{~h}$ and was then warmed to 0 ${ }^{\circ} \mathrm{C}$ and kept at that temperature for $30 \mathrm{~min}$. After confirmation of complete conversion by TLC, $50 \mathrm{ml}$ of a sat. aqu. solution of Rochelle's salt were added carefully and the mixture was stirred (ca. $30 \mathrm{~min}$ ) until separation of the phases was possible. After phase separation the aqueous layer was extracted with $\mathrm{CH}_{2} \mathrm{Cl}_{2}(3 \times 50 \mathrm{ml})$. The combined organic extracts were dried over $\mathrm{MgSO}_{4}$ and the solvent was removed under reduced pressure. After $\mathrm{FC}$ with $\mathrm{CH}_{2} \mathrm{Cl}_{2} / \mathrm{MeOH} 50 / 1$ alcohol 14 was obtained as a yellow oil ( $3.53 \mathrm{~g}, 51 \%$ over 3 steps).

$\mathbf{R}_{\mathbf{f}}\left(\mathrm{CH}_{2} \mathrm{Cl}_{2} / \mathrm{MeOH} \text { 20/1): 0.18. [ } \alpha\right]_{D}{ }^{25}:-32.3$ (c $\left.0.68, \mathrm{CHCl}_{3}\right)$.

${ }^{1} \mathrm{H}-\mathrm{NMR}\left(400 \mathrm{MHz}, \mathrm{CDCl}_{3}\right): \delta-0.16(\mathrm{~s}, 3 \mathrm{H}), 0.01(\mathrm{~s}, 3 \mathrm{H}), 0.87(\mathrm{~s}, 3 \mathrm{H}), 1.64(\mathrm{br} \mathrm{s}, 1 \mathrm{H})$, 2.37-2.45 (m, 1H), 2.45-2.53 (m, 1H), $2.58(\mathrm{~s}, 3 \mathrm{H}), 3.70(\mathrm{~s}, 3 \mathrm{H}), 4.04(\mathrm{~d}, \mathrm{~J}=4.7 \mathrm{~Hz}$, $2 \mathrm{H}), 4.78(\mathrm{dd}, J=7.1,5.5 \mathrm{~Hz}, 1 \mathrm{H}), 5.63(\mathrm{~m}, 2 \mathrm{H}), 7.20(\mathrm{~m}, 2 \mathrm{H}), 7.57(\mathrm{~s}, 1 \mathrm{H})$.

${ }^{13} \mathrm{C}$-NMR $\left(100 \mathrm{MHz}, \mathrm{CDCl}_{3}\right): \delta-4.9,4.6,13.8,18.3,25.9\left(3 \mathrm{CH}_{3}\right), 29.9,44.3,63.7$, $75.3,108.3,116.3,120.2,129.6,131.5,135.0,139.1,142.3,152.00$.

HRMS (ESI): $361.2304\left[\mathrm{M}+\mathrm{H}^{+}\right]$; calcd for $\left[\mathrm{C}_{20} \mathrm{H}_{32} \mathrm{~N}_{2} \mathrm{O}_{2} \mathrm{Si} \mathrm{M}+\mathrm{H}^{+}\right]$361.2306. 
IR [ATR, neat]: $2936(\mathrm{~m}), 2853(\mathrm{~m}), 1434(\mathrm{~m}), 1400(\mathrm{~m}), 1250(\mathrm{~m}), 1080(\mathrm{~s}), 834(\mathrm{~s})$, 776 (s).

$((1 R, 2 S)-2-((S)-2-(t e r t-B u t y l d i m e t h y l s i l y l o x y)-2-(1,2-d i m e t h y l-1 H$-benzo[d]imidazol-5yl)ethyl)cyclopropyl)methanol (18)<smiles></smiles>

To a stirred solution of $\mathrm{Et}_{2} \mathrm{Zn}(8.14 \mathrm{ml}$ of a $1 \mathrm{M}$ solution in hexane, $8.14 \mathrm{mmol})$ in anhydrous $\mathrm{CH}_{2} \mathrm{Cl}_{2}(18 \mathrm{ml})$ at $0{ }^{\circ} \mathrm{C}$ was added $\mathrm{CH}_{2} \mathrm{I}_{2}(4.36 \mathrm{~g}, 16.29 \mathrm{mmol})$. Please note the section about EXPLOSIONS!! in Charette, A. B.; Juteau, H.; Lebel, H.; Molinaro, C. J. Am. Chem. Soc. 1998, 120, 1194311952. The mixture was stirred at $0{ }^{\circ} \mathrm{C}$ for $10 \mathrm{~min}$ and a preformed solution of (+)(S,S)-2-butyl- $N, N, N^{\prime}, N^{\prime}$-tetramethyl-1,3,2-dioxaborolane-4,5-dicarboxamide 24

(Charette ligand) $(1.25 \mathrm{~g}, 4.64 \mathrm{mmol})$ and alcohol $17(734 \mathrm{mg}, 2.04 \mathrm{mmol})$ in anhydrous $\mathrm{CH}_{2} \mathrm{Cl}_{2}(28 \mathrm{ml})$ was rapidly added via syringe. The resulting mixture was stirred overnight and allowed to warm to r.t. during that time. Sat. aqu. $\mathrm{NH}_{4} \mathrm{Cl}(40 \mathrm{ml})$ was added and the mixture was extracted with $\mathrm{CH}_{2} \mathrm{Cl}_{2}(3 \times 30 \mathrm{ml})$. The combined organic extracts were washed with brine $(20 \mathrm{ml})$ and dried over $\mathrm{MgSO}_{4}$. After removal of the solvent under reduced pressure the residue was purified by FC with toluene/MeOH $8 / 1 \rightarrow 6 / 1$. Cyclopropane 18 was obtained as a colourless oil $(760 \mathrm{mg}$, quant).

$\mathbf{R}_{\mathbf{f}}\left(\mathrm{CH}_{2} \mathrm{Cl}_{2} / \mathrm{MeOH} \text { 20/1): 0.18. [ } \alpha\right]_{\mathrm{D}}{ }^{25}:-25.9$ (c $\left.1.20, \mathrm{CHCl}_{3}\right)$.

${ }^{1} \mathrm{H}-\mathrm{NMR}\left(400 \mathrm{MHz}, \mathrm{CDCl}_{3}\right): \delta-0.14(\mathrm{~s}, 3 \mathrm{H}), 0.03(\mathrm{~s}, 3 \mathrm{H}), 0.28(\mathrm{~m}, 2 \mathrm{H}), 0.66(\mathrm{~m}, 1 \mathrm{H})$, $0.76(\mathrm{~m}, 1 \mathrm{H}), 0.88(\mathrm{~s}, 3 \mathrm{H}), 1.31(\mathrm{br} \mathrm{s}, 1 \mathrm{H}), 1.55(\mathrm{~m}, 1 \mathrm{H}), 1.80(\mathrm{~m}, 1 \mathrm{H}), 2.58(\mathrm{~s}, 3 \mathrm{H})$, $3.34(\mathrm{~m}, 2 \mathrm{H}), 3.71(\mathrm{~s}, 3 \mathrm{H}), 4.85(\mathrm{t}, \mathrm{J}=6.0 \mathrm{~Hz}, 1 \mathrm{H}), 7.20-7.21(\mathrm{~m}, 2 \mathrm{H}), 7.59(\mathrm{~s}, 1 \mathrm{H})$.

${ }^{13} \mathrm{C}-\mathrm{NMR}\left(100 \mathrm{MHz}, \mathrm{CDCl}_{3}\right) \delta-4.9,-4.6,9.5,13.7,13.8,18.2,21.4,26.0\left(3 \mathrm{CH}_{3}\right)$, $29.9,45.2,67.0,75.2,108.3,116.3,120.3,134.9,139.5,142.1,151.9$.

HRMS (ESI): $397.2284\left[\mathrm{M}+\mathrm{Na}^{+}\right]$; calcd for $\left[\mathrm{C}_{21} \mathrm{H}_{34} \mathrm{~N}_{2} \mathrm{O}_{2} \mathrm{Si}+\mathrm{Na}^{+}\right]$397.2282.

IR [ATR, neat]: $2926(\mathrm{~m}), 2856(\mathrm{~m}), 1434(\mathrm{~m}), 1499(\mathrm{~m}), 1249(\mathrm{~m}), 1087(\mathrm{~s}), 1062$ (s), 835 (s), 775 (s).

(E)-3-((1R,2S)-2-((S)-2-(tert-Butyldimethylsilyloxy)-2-(1,2-dimethyl-1Hbenzo[d] imidazol-5-yl)ethyl)cyclopropyl)prop-2-en-1-ol (19)

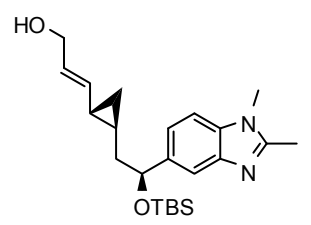


A. (E)-Ethyl 3-((1R,2S)-2-((S)-2-(tert-butyldimethylsilyloxy)-2-(1,2-dimethyl-1Hbenzo[d]imidazol-5-yl)ethyl)cyclopropyl)acrylate<smiles>CCOC(=O)C=CC1(CC(O)c2ccc3c(c2)nc(C)n3C)CC1</smiles>

A solution of alcohol $18(760 \mathrm{mg}, 2.02 \mathrm{mmol})$ in $5 \mathrm{ml}$ of $\mathrm{CH}_{2} \mathrm{Cl}_{2}$ was added dropwise to a premixed solution of oxalyl chloride $(3.03 \mathrm{mmol})$ and DMSO $(8.08 \mathrm{mmol})$ in $\mathrm{CH}_{2} \mathrm{Cl}_{2}(5 \mathrm{ml})$ at $-78{ }^{\circ} \mathrm{C}$ and the mixture was stirred for $1 \mathrm{~h} . \mathrm{Et}_{3} \mathrm{~N}(714 \mathrm{mg}, 7.07 \mathrm{mmol})$ was then added dropwise at $-78{ }^{\circ} \mathrm{C}$. The reaction mixture was subsequently allowed to warm to r.t. and stirred until conversion was complete (1h). Aqueous workup with sat. aqu. $\mathrm{NH}_{4} \mathrm{Cl}$, extraction with $\mathrm{CH}_{2} \mathrm{Cl}_{2}$, and the removal of solvent under reduced pressure gave the crude aldehyde, which was used without purification in the subsequent Wittig reaction. The crude aldehyde was dissolved in $35 \mathrm{ml}$ of $\mathrm{CH}_{2} \mathrm{Cl}_{2}$ and $\mathrm{Ph}_{3} \mathrm{PCHCO}_{2} \mathrm{Et}(844 \mathrm{mg}, 2.42 \mathrm{mmol}$ ) was added at r.t. The mixture was stirred for $15 \mathrm{~h}$ at that temperature. At this point additional $\mathrm{Ph}_{3} \mathrm{PCHCO}_{2} \mathrm{Et}(492 \mathrm{mg}, 1.41 \mathrm{mmol})$ was added and stirring was continued for additional 18h. After evaporation of the reaction mixture the residue was submitted to $\mathrm{FC}$ eluting with $\mathrm{CH}_{2} \mathrm{Cl}_{2} / \mathrm{MeOH} 50 / 1$. $\mathrm{FC}$ did not lead to complete removal of triphenylphosphine oxide and the mixture was used without further purification in the next step.

$\mathbf{R}_{\mathbf{f}}\left(\mathrm{CH}_{2} \mathrm{Cl}_{2} / \mathrm{MeOH} 20 / 1\right): 0.33$.

${ }^{1} \mathrm{H}-\mathrm{NMR}\left(400 \mathrm{MHz}, \mathrm{CDCl}_{3}\right): \delta-0.16(\mathrm{~s}, 3 \mathrm{H}), 0.02(\mathrm{~s}, 3 \mathrm{H}), 0.72(\mathrm{~m}, 2 \mathrm{H}), 0.88(\mathrm{~s}, 9 \mathrm{H})$, $1.09(\mathrm{~m}, 1 \mathrm{H}), 1.18-1.24(\mathrm{~m} 1 \mathrm{H}), 1.27(\mathrm{t}, \mathrm{J}=7.1 \mathrm{~Hz}, 3 \mathrm{H}), 1.50(\mathrm{~m}, 1 \mathrm{H}), 1.90(\mathrm{~m}, 1 \mathrm{H})$, $2.59(\mathrm{~s}, 3 \mathrm{H}), 3.71(\mathrm{~s}, 3 \mathrm{H}), 4.16(\mathrm{q}, \mathrm{J}=7.1 \mathrm{~Hz}, 2 \mathrm{H}), 4.83(\mathrm{dd}, \mathrm{J}=6.8,4.9 \mathrm{~Hz}, 1 \mathrm{H})$, $5.69(\mathrm{~d}, \mathrm{~J}=15.7 \mathrm{~Hz}, 1 \mathrm{H}), 6.39(\mathrm{dd}, \mathrm{J}=15.7,6.1 \mathrm{~Hz}, 1 \mathrm{H}), 7.18-7.19(\mathrm{~m}, 2 \mathrm{H}), 7.57(\mathrm{~s}$, $1 \mathrm{H})$.

${ }^{13} \mathrm{C}-\mathrm{NMR}\left(100 \mathrm{MHz}, \mathrm{CDCl}_{3}\right): \delta-4.95,-4.65,13.26,14.31,15.48,18.19,19.72,22.30$, 25.63, 25.86, 30.10, 45.26, 59.96, 74.84, 108.80, 115.30, 117.84, 133.04, 151.50, 153.27, 166.7.

HRMS (ESI): $465.2543\left[\mathrm{M}+\mathrm{Na}^{+}\right]$; calcd for $\left[\mathrm{C}_{25} \mathrm{H}_{38} \mathrm{~N}_{2} \mathrm{O}_{3} \mathrm{Si}+\mathrm{Na}^{+}\right]$465.2544.

IR [ATR, neat]: 2928 (m), 2855 (m), 1710 (s), 1437 (s), 1258 (m), 1047 (s), 835 (s), 721(s).

B. $(E)-3-((1 R, 2 S)-2-((S)-2-($ tert-Butyldimethylsilyloxy)-2-(1,2-dimethyl-1H-benzo[d] imidazol-5-yl)ethyl)cyclopropyl)prop-2-en-1-ol (19)

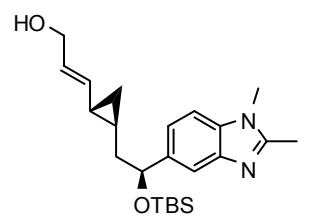

To a solution of the above crude Wittig product $(894 \mathrm{mg}, 2.02 \mathrm{mmol}$, assuming quantitative yields for the oxidation and Wittig steps) in $22 \mathrm{ml}$ of $\mathrm{CH}_{2} \mathrm{Cl}_{2}$ were slowly added $4.04 \mathrm{ml}(4.04 \mathrm{mmol})$ of a $1 \mathrm{M}$ DIBAL-H solution in $\mathrm{CH}_{2} \mathrm{Cl}_{2}$ at $-78{ }^{\circ} \mathrm{C}$. The reaction was left to stir for $50 \mathrm{~min}$ and was then warmed to $0{ }^{\circ} \mathrm{C}$ and kept at that temperature for $30 \mathrm{~min} .20 \mathrm{ml}$ of a sat. aqu. solution of Rochelle's salt were added 
carefully and the mixture was stirred (ca. $30 \mathrm{~min}$ ) until separation of the phases was possible. After phase separation the aqueous solution was extracted with $\mathrm{CH}_{2} \mathrm{Cl}_{2} \mathrm{(3x}$ $20 \mathrm{ml}$ ). The combined organic extracts were dried over $\mathrm{MgSO}_{4}$ and the solvent was removed under reduced pressure. After $\mathrm{FC}$ with $\mathrm{CH}_{2} \mathrm{Cl}_{2} / \mathrm{MeOH} 50 / 1$ allylic alcohol 19 was obtained as a yellow oil (526 mg, $65 \%$ over 3 steps).

$\mathbf{R}_{\mathbf{f}}\left(\mathrm{CH}_{2} \mathrm{Cl}_{2} / \mathrm{MeOH} 20 / 1\right): 0.23[\alpha]_{\mathbf{D}}{ }^{25}:+29.76$ (c 0.40, $\left.\mathrm{CHCl}_{3}\right)$.

${ }^{1} \mathrm{H}-\mathrm{NMR}\left(400 \mathrm{MHz}, \mathrm{CDCl}_{3}\right): \delta-0.13(\mathrm{~s}, 3 \mathrm{H}), 0.02(\mathrm{~s}, 3 \mathrm{H}), 0.43-0.47(\mathrm{~m}, 2 \mathrm{H}), 0.61-$ $0.69(\mathrm{~m}, 1 \mathrm{H}), 0.88(\mathrm{~s}, 9 \mathrm{H}), 0.90-0.97(\mathrm{~m}, 1 \mathrm{H}), 1.55$ (ddd, $\mathrm{J}=13.9,8.2,5.9 \mathrm{~Hz}, 1 \mathrm{H})$, 1.79-1.86 (m, 1H), $2.58(\mathrm{~s}, 3 \mathrm{H}), 3.71(\mathrm{~s}, 3 \mathrm{H}), 3.95-4.06(\mathrm{~m}, 2 \mathrm{H}), 4.86(\mathrm{t}, \mathrm{J}=6.0 \mathrm{~Hz}$, $1 \mathrm{H}), 5.04$ (dd, 15.3, 9.2 Hz, 1H), 5.47 (ddd, $J=15.3,7.3,5.6 \mathrm{~Hz}, 1 \mathrm{H}$ ), 7.19 (d, J = 0.9 $\mathrm{Hz}, 2 \mathrm{H}), 7.63$ (s, 1H).

${ }^{13} \mathrm{C}-\mathrm{NMR}\left(100 \mathrm{MHz}, \mathrm{CDCl}_{3}\right): \delta-5.0,-4.6,13.5,13.7,17.1,18.3,21.2,25.9\left(3 \mathrm{CH}_{3}\right)$, $29.9,44.9,63.8,75.0,108.1,117.6,120.0,126.9,134.9,137.1,139.0,141.8,152.0$.

HRMS (ESI): $423.2436\left[\mathrm{M}+\mathrm{Na}^{+}\right]$; calcd for $\left[\mathrm{C}_{23} \mathrm{H}_{36} \mathrm{~N}_{2} \mathrm{O}_{2} \mathrm{Si}+\mathrm{Na}^{+}\right]$423.2438.

IR [ATR, neat]: 3242 (b), 2925 (s), 2853 (s), 1520 (m), 1433 (m), 1400 (s), 1250 (s), 1083 (s), 835 (s), 775 (s).

3-((1R,2S)-2-((S)-2-(tert-Butyldimethylsilyloxy)-2-(1,2-dimethyl-1H-benzo[d]imidazol5-yl)ethyl)cyclopropyl)propan-1-ol (20)

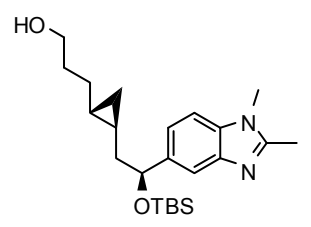

To a solution of allylic alcohol $19(526 \mathrm{mg}, 1.31 \mathrm{mmol})$ in anhydrous $\mathrm{MeOH}(13.1 \mathrm{ml})$ were added $112 \mathrm{mg}(0.47 \mathrm{mmol})$ of $\mathrm{CoCl}_{2} \cdot 6 \mathrm{H}_{2} \mathrm{O}$ and the blue solution was left stirring for $25 \mathrm{~min}$. A solution of $\mathrm{NaBH}_{4}(179 \mathrm{mg}, 4.72 \mathrm{mmol})$ in $7.8 \mathrm{ml} \mathrm{DMF}$ was then added dropwise. After 20 min, conversion was complete (based on MS analysis) and the reaction was quenched with water $(15 \mathrm{ml})$. After addition of $\mathrm{CH}_{2} \mathrm{Cl}_{2}(15 \mathrm{ml})$ the phases were separated and the aqueous phase was extracted with $\mathrm{CH}_{2} \mathrm{Cl}_{2}(3 \times 15$ $\mathrm{ml})$. The combined organic extracts were washed with brine and the brine reextracted with $\mathrm{CH}_{2} \mathrm{Cl}_{2}$. After filtration through a pad of celite, removal of the solvent under reduced pressure and $\mathrm{FC}\left(\mathrm{CH}_{2} \mathrm{Cl}_{2} / \mathrm{MeOH} 50 / 1 \rightarrow 5 / 1\right) 390 \mathrm{mg}$ of the desired alcohol 20 were obtained as a colorless oil (74\%).

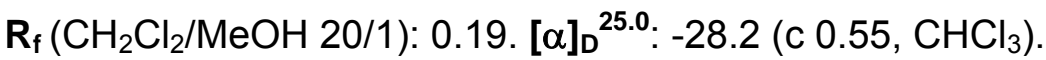

${ }^{1} \mathrm{H}-\mathrm{NMR}\left(400 \mathrm{MHz}, \mathrm{CDCl}_{3}\right): \delta-0.15(\mathrm{~s}, 3 \mathrm{H}), 0.02(\mathrm{~s}, 3 \mathrm{H}), 0.10-0.18(\mathrm{~m}, 2 \mathrm{H}), 0.34-0.42$ $(\mathrm{m}, 1 \mathrm{H}), 0.44-0.52(\mathrm{~m}, 1 \mathrm{H}), 0.87(\mathrm{~s}, 9 \mathrm{H}), 1.09-1.18(\mathrm{~m}, 1 \mathrm{H}), 1.30-1.46(\mathrm{~m}, 2 \mathrm{H}), 1.60$ $(\mathrm{m}, 2 \mathrm{H}), 1.79(\mathrm{dt}, \mathrm{J}=13.5,6.7 \mathrm{~Hz}), 2.58(\mathrm{~s}, 3 \mathrm{H}), 3.61(\mathrm{t}, \mathrm{J}=6.6 \mathrm{~Hz}, 2 \mathrm{H}), 3.70(\mathrm{~s}, 3 \mathrm{H})$, $4.79(\mathrm{t}, \mathrm{J}=6.3 \mathrm{~Hz}, 1 \mathrm{H}), 7.20-7.21(\mathrm{~m}, 2 \mathrm{H}), 7.59(\mathrm{~s}, 1 \mathrm{H})$.

${ }^{13} \mathrm{C}-\mathrm{NMR}\left(100 \mathrm{MHz}, \mathrm{CDCl}_{3}\right): \delta-4.9,-4.6,11.7,13.8,15.5,18.3,18.6,25.9\left(3 \mathrm{CH}_{3}\right)$, 29.9, 30.3, 32.7, 46.2, 62.7, 75.6, 108.2, 116.5, 120.3, 134.9, 139.8, 142.2, 151.9.

HRMS (ESI): $403.2775\left[\mathrm{M}+\mathrm{H}^{+}\right]$; calcd for $\left[\mathrm{C}_{23} \mathrm{H}_{39} \mathrm{~N}_{2} \mathrm{O}_{2} \mathrm{Si}+\mathrm{H}^{+}\right] 403.2773$.

IR [ATR, neat]: 3257 (b), 2926 (s), 2854 (s), 1520 (m), 1433 (m), 1398 (s), 1250 (s), 1079 (s), 834 (s), 775 (s). 
5-((S)-2-((1S,2R)-2-allylcyclopropyl)-1-(tert-butyldimethylsilyloxy)ethyl)-1,2-dimethyl$1 H$-benzo[d]imidazole (21)

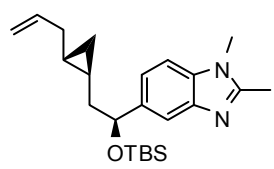

Alcohol $20(0.49 \mathrm{~g}, 1.22 \mathrm{mmol})$ and 2-nitrophenyl selenocyanate $(1.38 \mathrm{~g}, 6.08 \mathrm{mmol})$ were dissolved in $17 \mathrm{ml}$ of THF. Bu $\mathrm{P}(1.23 \mathrm{~g}, 6.08 \mathrm{mmol})$ was then slowly added to the mixture at a temperature of $30^{\circ} \mathrm{C}$. After $90 \mathrm{~min}$ the formation of the seleno ether was complete, $\mathrm{NaHCO}_{3}(3 \mathrm{~g}, 36 \mathrm{mmol})$ was added in one portion and $4 \mathrm{ml}$ of a $30 \%$ sol. of $\mathrm{H}_{2} \mathrm{O}_{2}$ in water were added dropwise. The mixture was further heated to 45 $50^{\circ} \mathrm{C}$. After approx. $45 \mathrm{~min}$ at that temperature the TLC showed virtually complete consumption of the oxidized starting material. The reaction mixture was poured into a 1/1/6 mixture of water, sat. aqu. $\mathrm{NH}_{4} \mathrm{Cl}$, and $\mathrm{CH}_{2} \mathrm{Cl}_{2}$ and the whole mixture was stirred vigorously for a few minutes. After phase separation and extraction of the aqueous phase with $\mathrm{CH}_{2} \mathrm{Cl}_{2}$ (3 times) the combined organic extracts were dried over $\mathrm{MgSO}_{4}$ and the solvent was removed in vacuo. $\mathrm{FC}$ with $\mathrm{CH}_{2} \mathrm{Cl}_{2} / \mathrm{MeOH} 100 / 1$ followed by a second column with toluene/MeOH 15/1 gave olefin 21 as a yellow oil (422 mg, $90 \%)$.

$\mathbf{R}_{\mathbf{f}}\left(\mathrm{CH}_{2} \mathrm{Cl}_{2} / \mathrm{MeOH} \text { 20/1): 0.40. [ } \alpha\right]_{\mathrm{D}}{ }^{25.0}:-29.5$ (c $\left.0.78, \mathrm{CHCl}_{3}\right)$.

${ }^{1} \mathrm{H}-\mathrm{NMR}\left(400 \mathrm{MHz}, \mathrm{CDCl}_{3}\right): \delta-0.15(\mathrm{~s}, 3 \mathrm{H}), 0.02(\mathrm{~s}, 3 \mathrm{H}), 0.15-0.22(\mathrm{~m}, 1 \mathrm{H}), 0.45-0.57$ $(\mathrm{m}, 1 \mathrm{H}), 0.87(\mathrm{~s}, 9 \mathrm{H}), 1.39$ (ddd, $J=13.5,7.5,5.7 \mathrm{~Hz}, 1 \mathrm{H}), 1.79-1.89(\mathrm{~m}, 2 \mathrm{H}), 2.02-$ $2.09(\mathrm{~m}, 1 \mathrm{H}), 2.59(\mathrm{~s}, 3 \mathrm{H}), 3.70(\mathrm{~s}, 3 \mathrm{H}), 4.80(\mathrm{dd}, \mathrm{J}=7.0,5.8,1 \mathrm{H}), 4.93-4.96(\mathrm{~m}, 1 \mathrm{H})$, 5.00-5.05 (m, 1H), 5.83 (ddt, $J=16.6,10.2,6.4 \mathrm{~Hz}, 1 \mathrm{H}), 7.18(\mathrm{~m}, 1 \mathrm{H}), 7.21(\mathrm{~s}, 1 \mathrm{H})$, $7.60(\mathrm{~s}, 1 \mathrm{H})$.

${ }^{13} \mathrm{C}-\mathrm{NMR}\left(100 \mathrm{MHz}, \mathrm{CDCl}_{3}\right): \delta-4.9,-4.6,11.2,13.8,15.2,17.8,18.2,21.4,25.9$ $\left(3 \mathrm{CH}_{3}\right), 29.9,37.9,46.2,75.7,108.2,114.3,116.4,120.4,134.8,138.0,140.0,151.8$.

HRMS (ESI): $385.2667\left[\mathrm{M}+\mathrm{H}^{+}\right]$; calcd for $\left[\mathrm{C}_{23} \mathrm{H}_{37} \mathrm{~N}_{2} \mathrm{OSi}+\mathrm{H}^{+}\right]$385.2670.

IR [ATR, neat]: 2953 (m), 2926 (s), 2853 (s), 2169 (m), 1529 (s), 1432 (m), 1350 (s), 1249 (s), 1087 (s), 835 (s), 776 (s).

(S)-2-((1S,2R)-2-allylcyclopropyl)-1-(1,2-dimethyl-1H-benzo[d]imidazol-5-yl)ethanol (5)

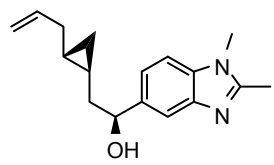

Camphorsulfonic acid (65 $\mathrm{mg}, 0.28 \mathrm{mmol}$ ) was carefully added to a solution of $27 \mathrm{mg}$ $(0.07 \mathrm{mmol})$ of protected alcohol 21 in $1.75 \mathrm{ml}$ of $\mathrm{MeOH}$ and $1.75 \mathrm{ml}$ of $\mathrm{CH}_{2} \mathrm{Cl}_{2}$ at 0 ${ }^{\circ} \mathrm{C}$. The mixture was then allowed to warm to r.t. and was stirred overnight. After careful quenching with sat. aqu. $\mathrm{NaHCO}_{3}(5 \mathrm{ml})$, the mixture was extracted with $\mathrm{CH}_{2} \mathrm{Cl}_{2}(3 \times 5 \mathrm{ml})$ and the combined extracts were dried over $\mathrm{MgSO}_{4}$. After removal of the solvent in vacuo and $\mathrm{FC}$ of the residue with $\mathrm{CH}_{2} \mathrm{Cl}_{2} / \mathrm{MeOH} 20 / 1$, the free alcohol 5 was obtained as an orange solid (12 $\mathrm{mg}, 65 \%)$.

$\mathbf{R}_{\mathbf{f}}\left(\mathrm{CH}_{2} \mathrm{Cl}_{2} / \mathrm{MeOH} 20 / 1\right): 0.18$. Mp.: $138-139^{\circ} \mathrm{C} .[\alpha]_{\mathbf{D}}{ }^{25.0}:-24.6$ (c 0.48, $\left.\mathrm{CHCl}_{3}\right)$. 
${ }^{1} \mathrm{H}-N M R\left(400 \mathrm{MHz}, \mathrm{CDCl}_{3}\right): \delta 0.21-0.24(\mathrm{~m}, 1 \mathrm{H}), 0.45-0.53(\mathrm{~m}, 1 \mathrm{H}), 0.57-0.65(\mathrm{~m}$, $1 \mathrm{H}), 0.90(\mathrm{dt}, J=13.6,7.2 \mathrm{~Hz}, 1 \mathrm{H}), 1.65-1.81(\mathrm{~m}, 2 \mathrm{H}), 1.95(\mathrm{t}, 6.7 \mathrm{~Hz}), 2.21(\mathrm{~b}, 1 \mathrm{H})$, $2.59(\mathrm{~s}, 3 \mathrm{H}), 3.71(\mathrm{~s}, 3 \mathrm{H}), 4.86(\mathrm{~m}, 1 \mathrm{H}), 4.95-4.99(\mathrm{~m}, 1 \mathrm{H}), 5.01-5.07(\mathrm{~m}, 1 \mathrm{H}), 5.86$ (ddt, $J=16.7,10.2,6.5 \mathrm{~Hz}, 1 \mathrm{H}), 7.22-7.25(\mathrm{~d}, \mathrm{~J}=8.4 \mathrm{~Hz}, 1 \mathrm{H}), 7.28(\mathrm{dd}, \mathrm{J}=8.4,1.4$ $\mathrm{Hz}, 1 \mathrm{H}), 7.63(\mathrm{~s}, 1 \mathrm{H})$.

${ }^{13} \mathrm{C}-\mathrm{NMR}\left(100 \mathrm{MHz}, \mathrm{CDCl}_{3}\right): \delta 11.0,13.7,15.1,18.0,29.7,29.9,37.9,43.9,53.4$, 75.2, 108.7, 114.7, 116.4, 120.3, 137.9, 138.8, 142.2.

HRMS (ESI): $271.1805\left[\mathrm{M}+\mathrm{H}^{+}\right]$; calcd for $\left[\mathrm{C}_{17} \mathrm{H}_{23} \mathrm{~N}_{2} \mathrm{O}+\mathrm{H}^{+}\right] 271.1805$.

IR [ATR, neat]: 3148 (b), 2925 (s), 2853 (m), 1523 (s), 1486 (s), 1427 (s), 1399 (s), $1339(\mathrm{~s}), 1258(\mathrm{w}), 1079(\mathrm{~m}), 808(\mathrm{~s})$.

\section{Assembly of target structures 1 and 2}

$(6 R, 7 S, 8 S)-((S)-2-((1 S, 2 R)-2-a l l y l c y c l o p r o p y l)-1-(1,2-d i m e t h y l-1 H$-benzo[d]imidazol5-yl)ethyl) 7-(tert-butyldimethylsilyloxy)-4,4,6,8-tetramethyl-5-oxodec-9-enoate (22)

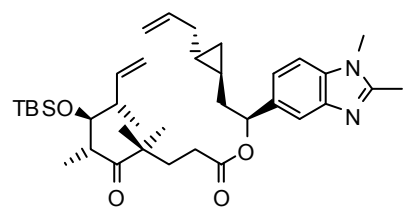

EDC (15 mg, $78 \mu \mathrm{mol})$ was added to a solution of alcohol $5(20 \mathrm{mg}, 74 \mu \mathrm{mol})$, acid 4 $(23 \mathrm{mg}, 63 \mu \mathrm{mol})$ and DMAP $(6.9 \mathrm{mg}, 57 \mu \mathrm{mol})$ in dry $\mathrm{CH}_{2} \mathrm{Cl}_{2}(1 \mathrm{ml})$ at $0^{\circ} \mathrm{C}$. The mixture was stirred at r.t. for $24 \mathrm{~h}$ and the reaction quenched with $2 \mathrm{ml}$ of water. After extraction with $\mathrm{CH}_{2} \mathrm{Cl}_{2}(3 \times 5 \mathrm{ml})$ the combined organic extracts were washed with brine, which was re-extracted once with $\mathrm{CH}_{2} \mathrm{Cl}_{2}$. After drying over $\mathrm{MgSO}_{4}$ the solvent was removed in vacuo and the residue was purified by $\mathrm{FC}\left(\mathrm{CH}_{2} \mathrm{Cl}_{2} / \mathrm{MeOH} 50 / 1\right)$ to provide $34 \mathrm{mg}(87 \%)$ of diene $\mathbf{2 2}$ as a yellow oil.

$\mathbf{R}_{\mathbf{f}}\left(\mathrm{CH}_{2} \mathrm{Cl}_{2} / \mathrm{MeOH} 20 / 1\right): 0.35$. [ $\left.\alpha\right]_{\mathrm{D}}{ }^{25}$ : -37.2 (c $0.41, \mathrm{CHCl}_{3}$ ).

${ }^{1} \mathrm{H}-\mathrm{NMR}\left(400 \mathrm{MHz}, \mathrm{CDCl}_{3}\right): \delta 0.08(\mathrm{~s}, 6 \mathrm{H}), 0.18-0.22(\mathrm{~m}, 2 \mathrm{H}), 0.36-0.43(\mathrm{~m}, 1 \mathrm{H})$, 0.57-0.65 (m, 1H), $0.91(\mathrm{~s}, 9 \mathrm{H}), 1.01(\mathrm{~d}, 3 \mathrm{H}), 1.03(\mathrm{~d}, 3 \mathrm{H}), 1.08(\mathrm{~s}, 3 \mathrm{H}), 1.13(\mathrm{~s}, 3 \mathrm{H})$, 1.73-1.89 (m, 5H), 1.95-2.08 (m, 2H), 2.21-2.26 (m, 2H), $2.61(\mathrm{~s}, 3 \mathrm{H}), 3.00-3.08(\mathrm{~m}$, $1 \mathrm{H}), 3.71(\mathrm{~s}, 3 \mathrm{H}), 4.92-5.04(\mathrm{~m}, 4 \mathrm{H}), 5.76-5.92(\mathrm{~m}, 3 \mathrm{H}), 7.24-7.25(\mathrm{~m}, 2 \mathrm{H}), 7.66(\mathrm{~s}$, $1 \mathrm{H})$.

${ }^{13} \mathrm{C}-\mathrm{NMR}\left(100 \mathrm{MHz}, \mathrm{CDCl}_{3}\right): \delta-3.8,-3.5,11.3,13.7,14.7,16.2,17.7,18.5(2 \mathrm{C}), 24.4$, 24.7, 26.2 (3C) , 29.9, 30.2, 34.2, 37.8, 41.1, 43.4, 44.9, 47.4, 76.5, 76.9, 108.6, 114.6, 115.4, 116.9, 121.5, 123.2, 125.9, 135.3, 137.7, 139.8, 152.3, 172.8, 218.4.

HRMS (ESI): $645.4065\left[\mathrm{M}+\mathrm{Na}^{+}\right]$; calcd for $\left[\mathrm{C}_{37} \mathrm{H}_{58} \mathrm{~N}_{2} \mathrm{O}_{4} \mathrm{Si}+\mathrm{Na}^{+}\right] 645.4058$.

IR [ATR, neat]: 3070 (w), 2957 (m), 2930 (s), 1732 (s), 1694 (s), 1520 (m), 1253 (s), 1001 (s), 837 (s), 798 (s). 
(1S,3S,10R,11S,12S,16S,E)-11-(tert-butyldimethylsilyloxy)-3-(1,2-dimethyl-1Hbenzo[d]imidazol-5-yl)-8,8,10,12-tetramethyl-4-oxabicyclo[14.1.0]heptadec-13-ene5,9-dione (23)

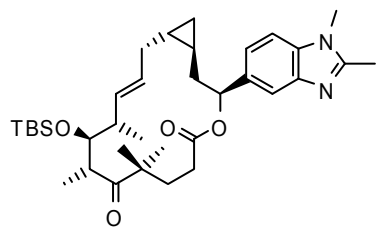

A solution of diene $22(69 \mathrm{mg}, 111 \mu \mathrm{mol})$ in toluene $(220 \mathrm{ml})$ was heated to reflux and treated with a solution of $2^{\text {nd }}$ generation Grubbs catalyst $(9 \mathrm{mg}, 11 \mu \mathrm{mol})$ in toluene $(1$ $\mathrm{ml})$. The solution was stirred for $15 \mathrm{~min}$ and cooled to r.t., filtered through a plug of silica and the precipitate rinsed with toluene/MeOH 10/1. The filtrate was concentrated in vacuo and the residue was purified by $\mathrm{FC}\left(\mathrm{CH}_{2} \mathrm{Cl}_{2} / \mathrm{MeOH} 50 / 1\right)$ to give the desired macrolactone 23 as a yellow oil (62 $\mathrm{mg}, 94 \%$ ).

$\mathbf{R}_{\mathbf{f}}\left(\mathrm{CH}_{2} \mathrm{Cl}_{2} / \mathrm{MeOH} \text { 20/1): 0.28. [ } \alpha\right]_{\mathrm{D}}{ }^{25.0}:-24.4$ (c 0.40, $\left.\mathrm{CHCl}_{3}\right)$.

${ }^{1} \mathrm{H}-\mathrm{NMR}\left(400 \mathrm{MHz}, \mathrm{CDCl}_{3}\right): \delta 0.09(\mathrm{~s}, 6 \mathrm{H}), 0.16-0.31(\mathrm{~m}, 2 \mathrm{H}), 0.61-0.79(\mathrm{~m}, 2 \mathrm{H})$, $0.94(\mathrm{~s}, 9 \mathrm{H}), 0.99-1.00(\mathrm{~m}, 6 \mathrm{H}), 1.09(\mathrm{~d}, \mathrm{~J}=7.01 \mathrm{~Hz}, 3 \mathrm{H}), 1.37(\mathrm{~s}, 3 \mathrm{H}), 1.37-1.47(\mathrm{~m}$, $2 \mathrm{H}), 1.75-1.84(\mathrm{~m}, 1 \mathrm{H}), 1.91-2.03(\mathrm{~m}, 2 \mathrm{H}), 2.03-2.22(\mathrm{~m}, 2 \mathrm{H}), 2.25-2.37(\mathrm{~m}, 1 \mathrm{H})$, 2.49-2.57 (m, 1H), $2.59(\mathrm{~s}, 3 \mathrm{H}), 3.05(\mathrm{dd}, \mathrm{J}=7.0,9.0,1 \mathrm{H}), 3.70(\mathrm{~s}, 3 \mathrm{H}), 3.87(\mathrm{dd}, \mathrm{J}=$ $9.1 \mathrm{~Hz}, 1.1 \mathrm{~Hz}, 1 \mathrm{H}$ ), 5.38 (ddd, $\mathrm{J}=15.7,10.2,3.5 \mathrm{~Hz}, 1 \mathrm{H}$ ), 5.69 (ddd, $\mathrm{J}=15.7,8.0$, $1.3 \mathrm{~Hz}, 1 \mathrm{H}), 6.06$ (d, J = $10.4 \mathrm{~Hz}, 1 \mathrm{H}), 7.21(\mathrm{~s}, 2 \mathrm{H}), 7.59(\mathrm{~s}, 1 \mathrm{H})$.

${ }^{13} \mathrm{C}-\mathrm{NMR}\left(100 \mathrm{MHz}, \mathrm{CDCl}_{3}\right): \delta-3.5,-3.2,9.8,13.8,17.3,17.4,18.6,19.0,21.5,22.2$, 26.0, 26.1, 26.3, 29.9, 30.9, 33.5, 38.9, 41.3, 41.9, 45.8, 47.5, 77.2, 77.6, 108.7, $116.0,120.9,131.0,131.2,135.4,136.0,152.4,172.3,217.7$.

HRMS (ESI): $617.3744\left[\mathrm{M}+\mathrm{Na}^{+}\right]$; calcd for $\left[\mathrm{C}_{35} \mathrm{H}_{54} \mathrm{~N}_{2} \mathrm{O}_{4} \mathrm{Si}+\mathrm{Na}^{+}\right] 617.3745$.

IR [ATR, neat]: 2956 (s), 2930 (s), 2857 (m), 1729 (s), 1695 (s), 1473 (m), 1255 (s), 1033 (s), 980 (s), 835 (s), 775 (s).

(1S,3S,10R,11S,12S,16S,E)-3-(1,2-dimethyl-1H-benzo[d]imidazol-5-yl)-11-hydroxy8,8,10,12-tetramethyl-4-oxabicyclo[14.1.0]heptadec-13-ene-5,9-dione (2)<smiles>Cc1nc2cc(C(CC3CC3)OC3CC4CCC3C(=O)C4(C)O)ccc2n1C</smiles>

Macrolactone $23(50 \mathrm{mg}, 84 \mu \mathrm{mol})$ was dissolved in $10 \mathrm{ml}$ of a $20 \% \mathrm{v} / \mathrm{v}$ solution of TFA in $\mathrm{CH}_{2} \mathrm{Cl}_{2}$ and the mixture was stirred at r.t. for $18 \mathrm{~h}$. The mixture was worked up by carefully adding sat. aqu. $\mathrm{NaHCO}_{3}$ until the evolution of $\mathrm{CO}_{2}$ ceased (ca. $10 \mathrm{ml}$ ). After extraction with $\mathrm{CH}_{2} \mathrm{Cl}_{2}(3 \times 10 \mathrm{ml})$ and drying over $\mathrm{MgSO}_{4}$ the solvent was removed under reduced pressure. The resulting beige residue was purified using $\mathrm{FC}$ $\left(\mathrm{CH}_{2} \mathrm{Cl}_{2} / \mathrm{MeOH} 50 / 1\right)$ furnishing $32 \mathrm{mg}$ of target structure 2 as a white solid $(80 \%)$.

$\mathbf{R}_{\mathbf{f}}\left(\mathrm{CH}_{2} \mathrm{Cl}_{2} / \mathrm{MeOH} 10 / 1\right): 0.38$. $[\alpha]_{\mathbf{D}}{ }^{25}$ : -35.0 (c $\left.0.60, \mathrm{CHCl}_{3}\right)$. 
${ }^{1} \mathrm{H}-\mathrm{NMR}\left(500 \mathrm{MHz},\left(\mathrm{CD}_{3}\right)_{2} \mathrm{SO}\right): \delta 0.18-0.23(\mathrm{~m}, 2 \mathrm{H}), 0.66-0.73(\mathrm{~m}, 2 \mathrm{H}), 0.92(\mathrm{~s}, 3 \mathrm{H})$, $0.96(\mathrm{~d}, \mathrm{~J}=6.7 \mathrm{~Hz}, 3 \mathrm{H}), 1.07(\mathrm{~d}, \mathrm{~J}=6.7 \mathrm{~Hz}, 3 \mathrm{H}), 1.23-1.43(\mathrm{~m}, 3 \mathrm{H}), 1.29(\mathrm{~s}, 3 \mathrm{H})$, 1.72-1.85 (m, 2H), 1.89-1.97 (m, 2H), $2.10(\mathrm{~d}, \mathrm{~J}=15 \mathrm{~Hz}, 1 \mathrm{H}), 2.28-2.37(\mathrm{~m}, 1 \mathrm{H}), 2.50$ $(\mathrm{s}, 3 \mathrm{H}), 2.87-2.94(\mathrm{~m}, 1 \mathrm{H}), 3.48-3.52(\mathrm{~m}, 1 \mathrm{H}), 3.70(\mathrm{~s}, 3 \mathrm{H}), 4.86(\mathrm{~d}, \mathrm{~J}=6.7 \mathrm{~Hz}, 1 \mathrm{H})$, 5.24-5.31 (m, 1H), 5.64-5.71 (m, 1H), $6.01(\mathrm{~d}, \mathrm{~J}=11.0 \mathrm{~Hz}, 1 \mathrm{H}), 7.15(\mathrm{dd}, \mathrm{J}=8.5,1.5$ $\mathrm{Hz}, 1 \mathrm{H}), 7.39-7.43(\mathrm{~m}, 2 \mathrm{H})$.

${ }^{13} \mathrm{C}-\mathrm{NMR}\left(125 \mathrm{MHz},\left(\mathrm{CD}_{3}\right)_{2} \mathrm{SO}\right): \delta 9.2,13.5,15.2,16.8,17.2,18.5,21.7,21.8,25.4$, 29.7, 30.5, 32.7, 38.3, 41.2, 45.0, 46.8, 74.4, 77.0, 109.5, 115.4, 119.5, 130.3, 131.2, 134.9, 135.3, 142.1, 152.7, 171.5, 217.2.

HRMS (ESI): $503.2879\left[\mathrm{M}+\mathrm{Na}^{+}\right]$; calcd for $\left[\mathrm{C}_{29} \mathrm{H}_{40} \mathrm{~N}_{2} \mathrm{O}_{4}+\mathrm{Na}^{+}\right] 503.2880$.

IR [ATR, neat]: 3189 (b), 2961 (m), 2952 (s), 1730 (s), 1693 (s), 1433 (m), 1258 (s), $977(\mathrm{~s}), 798(\mathrm{~m}), 735(\mathrm{~m})$.

(1S,3S,10R,11S,12S,16R)-3-(1,2-dimethyl-1H-benzo[d]imidazol-5-yl)-11-hydroxy8,8,10,12-tetramethyl-4-oxabicyclo[14.1.0]heptadecane-5,9-dione (1)

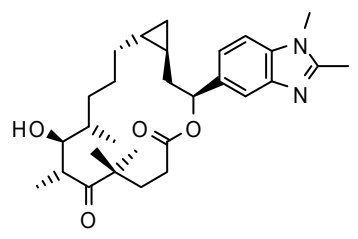

Macrolactone 2 (4.5 mg, $9 \mu \mathrm{mol}$ ) was dissolved in $6 \mathrm{ml}$ of $\mathrm{CH}_{2} \mathrm{Cl}_{2}$ (degassed by three freeze-pump-thaw cycles) and the solution was transferred into a flask containing 12 $\mathrm{mg}(15 \mu \mathrm{mol})$ of (tricyclohexylphosphine)(1,5,-cyclooctadiene)(pyridine) iridium (I) hexafluorophosphate (Crabtree's catalyst) under an Ar atmosphere. The mixture was then vigorously stirred under a atmosphere of $\mathrm{H}_{2}$ at $0{ }^{\circ} \mathrm{C}$. After $2 \mathrm{~h}$ of continuous stirring it was warmed to r.t. and stirred for an additional hour until the reaction was complete. The solvent was removed in vacuo and the crude product was purified by FC eluting with $\mathrm{CH}_{2} \mathrm{Cl}_{2} / \mathrm{MeOH} 50 / 1 \rightarrow 25 / 1$. After further purification by preparative

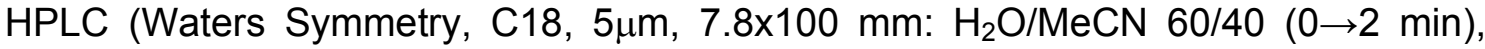
$\mathrm{H}_{2} \mathrm{O} / \mathrm{MeCN} 60 / 40 \rightarrow 10 / 90(2 \rightarrow 30 \mathrm{~min}$ ), compound dissolved in DMSO for injection, $\tau_{r}=10.56 \mathrm{~min}$, multiple injections) and lyophilization $2.8 \mathrm{mg}(62 \%)$ of epothilone analog 1 were obtained as a fluffy white solid.

$\mathbf{R}_{\mathbf{f}}\left(\mathrm{CH}_{2} \mathrm{Cl}_{2} / \mathrm{MeOH} \text { 10/1): 0.38. [ } \alpha\right]_{\mathbf{D}}{ }^{25}:-21.41$ (c 1.52, $\left.\mathrm{CHCl}_{3}\right)$.

${ }^{1} \mathrm{H}-\mathrm{NMR}\left(500 \mathrm{MHz},\left(\mathrm{CD}_{3}\right)_{2} \mathrm{SO}\right): \delta$ 0.09-0.21 (m, 2H), 0.53-0.61 (m, 1H), 0.77-0.83 (m, $1 \mathrm{H}), 0.86-1.40(\mathrm{~m}, 6 \mathrm{H}) 0.87(\mathrm{~d}, \mathrm{~J}=5.7 \mathrm{~Hz}, 3 \mathrm{H}), 0.91(\mathrm{~s}, 3 \mathrm{H}), 1.06(\mathrm{~d}, \mathrm{~J}=6.6 \mathrm{~Hz}, 3 \mathrm{H})$, $1.30(\mathrm{~s}, 3 \mathrm{H}), 1.40-1.48(\mathrm{~m}, 1 \mathrm{H}), 1.58-1.66(\mathrm{~m}, 1 \mathrm{H}), 1.72-1.88(\mathrm{~m}, 2 \mathrm{H}), 1.97-2.05(\mathrm{~m}$, $1 \mathrm{H}), 2.11(\mathrm{~d}, \mathrm{~J}=14.3 \mathrm{~Hz}, 1 \mathrm{H}), 2.25-2.32(\mathrm{~m}, 1 \mathrm{H}), 2.50(\mathrm{~s}, 3 \mathrm{H}), 3.15-3.21(\mathrm{~m}, 1 \mathrm{H})$, 3.49-3.56 (m, 1H), $3.69(\mathrm{~s}, 3 \mathrm{H}), 4.57(\mathrm{~d}, \mathrm{~J}=6.7 \mathrm{~Hz}, 1 \mathrm{H}), 5.94(\mathrm{~d}, \mathrm{~J}=11.0 \mathrm{~Hz}, 1 \mathrm{H})$, $7.13(\mathrm{~d}, \mathrm{~J}=8.1 \mathrm{~Hz}, 1 \mathrm{H}), 7.38-7.43(\mathrm{~m}, 2 \mathrm{H})$.

${ }^{13} \mathrm{C}-\mathrm{NMR}\left(125 \mathrm{MHz},\left(\mathrm{CD}_{3}\right)_{2} \mathrm{SO}\right): \delta 9.9,13.4,17.0,17.9,18.1,18.4,22.4,25.1,25.3$, $27.8,29.7,30.4,33.4,34.1,35.3,41.4,43.5,46.9,76.1,77.1,109.5,115.3,119.5$, 135.0, 135.3, 141.9, 152.7, 171.3, 217.7.

HRMS (ESI): $505.3036\left[\mathrm{M}+\mathrm{Na}^{+}\right]$; calcd for $\left[\mathrm{C}_{29} \mathrm{H}_{42} \mathrm{~N}_{2} \mathrm{O}_{4}+\mathrm{Na}^{+}\right]$505.3037. 
IR [ATR, neat]: 3172 (b), 2925 (s), 2852 (s), 2360 (m), 1734 (s), 1691 (m), 1458 (m), $1262(\mathrm{~s}), 1122,1023,848(\mathrm{~s}), 797(\mathrm{~s}), 737(\mathrm{~m})$.

\section{References}

(S1) Inukai, T.; Yoshizawa, R. J. Org. Chem. 1967, 32, 404-407.

(S2) Walkup, R. D.; Kahl, J. D.; Kane, R. R. J. Org. Chem. 1998, 63, 9113-9116.

(S3) A SciFinder search for acid 14 returned two (non-patent) references: a) Semple, G.; Skinner, P. J.; Cherrier, M. C.; Webb, P. J.; Sage, C. R.; Tamura, S. Y.; Chen, R.; Richman, J. G.; Connolly, D. T. J. Med. Chem. 2006, 49, 12271230. b) Kotovskaya, S. K.; Mokrushina, G. A.; Suetina, T. A.; Chupakhin, O. N.; Zinchenko, E. Ya.; Lesovaya, Z. I.; Mezentsev, A. S.; Chernyshov, A. I.; Samoilova, L. N. Khimiko-Farmatsevticheskii Zhurnal 1989, 23, 952-956. However, ref. a) neither describes an experimental procedure for the preparation of $\mathbf{1 4}$ nor does it provide any analytical data for the compound. Reference b) was not retrieved.

(S4) Zubarovskii, V. M.; Moskaleva, R. N.; Bachurina, M. P. Zhurnal Obshchei Khimii 1962, 32, 1581-1586. (No other reference was retrieved in a SciFinder search on 1,2-Dimethyl-1H-benzo[d]imidazole-5-carboxylic acid).

(S5) Zubarovskii, V. M.; Moskaleva, R. N.; Bachurina, M. P. Khimiya Geterotsiklicheskikh Soedinenii 1965, 4, 571-575: This reference describes the synthesis of (1,2-Dimethyl-1H-benzo[d]imidazol-5-yl)methanol through LAH reduction of 1,2-Dimethyl-1H-benzo[d]imidazole-5-carboxylic acid and the subsequent oxidation of this alcohol to 8 with $\mathrm{CrO}_{3}$ in $\mathrm{AcOH}$ ).

A SciFinder search on aldehyde 8 provided also a second reference: Winans, K. A.; Bertozzi, C. R. Chem. Biol. 2002, 9, 113-129. However, this reference neither describes an experimental procedure for the preparation of $\mathbf{8}$ nor does it provide any analytical data for the compound. 